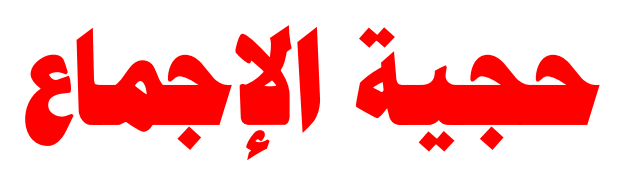

دكثّور

ناصر ضيف الله مطلق الحربي

رئيس قسم التربية الإسلامية في وزارة

التربية والتعليم، وإمام متطوع في وزارة

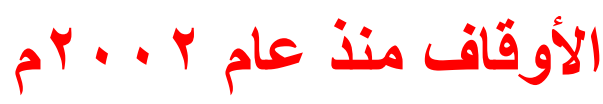


حجية الإجماع

$-1 T \wedge \varepsilon=$ 
ناصر ضيف الله مطلق الحربي. قسم أصول الفقه، كلية الشريعة والدر اسات الإسلامية، جامعة الكويت، الكويت. البريد الالكتروني: aboabdallah078@gmail.com

الملخص:

يهدف هذا البحث إلى بيان حجية الإجماع، وقد انتظم في مقدمة وأربعة مباحث وخاتمة ، تناول في تمهيد: تعريف الإجماع وحجيته وبيان منزلته، المبحث الأول: أقسام الإجماع، وشروطه، وفي المبحث الثاني: أركان الإجماع وأنواعه، وفي المبحث الثالث: الأحكام المترتبة على الإجماع، وفي المبحث الرابع: التطبيقات المعاصرة لالاجماع و المنهج المنبع، منهج الاستقراء الناقص، و المنهج الوصفي. النتائج:

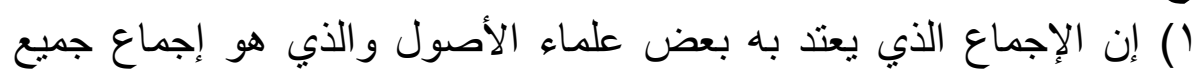

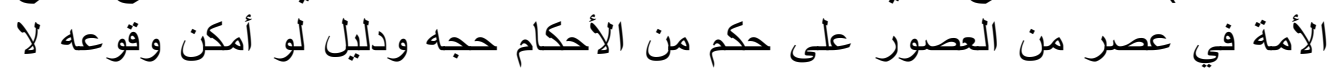

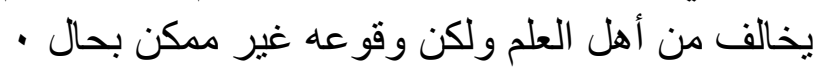

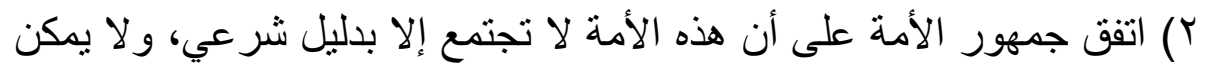

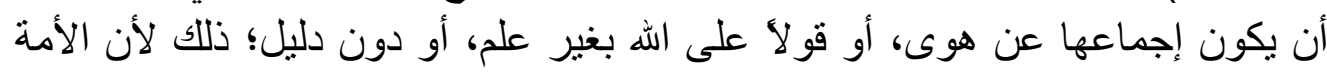

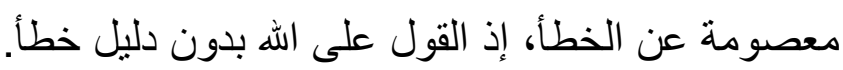

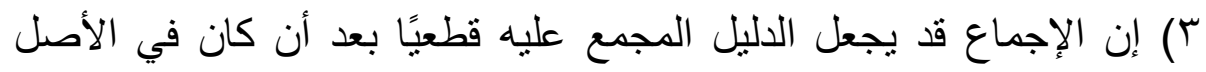

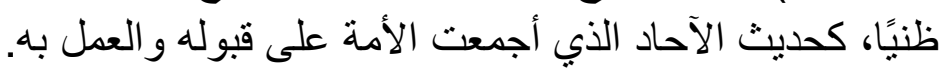

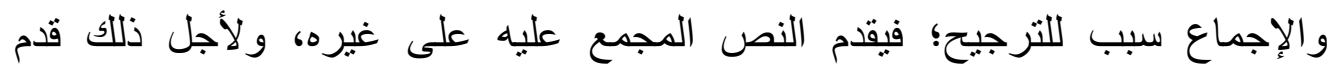
الأصوليون الإجماع على الكتاب و السنة. الكلمات المقتاحية: حجية ، الإجماع، المخالفين ، الاستنباط ، قطعيا. 


\section{Authentic consensus.}

Nasser Dhaifallah Mutlaq Al-Harbi.

Department Fundamentals of Jurisprudence, College Sharia and Islamic Studies, University Kuwait, Kuwait.

\section{E-mail: aboabdallah078@gmail.com}

\section{Abstract:}

This research aims to explain the authority of consensus, and it is organized into an introduction, four sections and a conclusion, dealing in a preface: the definition of consensus, its authority and its status, the first topic: the sections of consensus and its conditions, and in the second topic: the pillars of consensus and its types, and in the third topic: the provisions arising from consensus And in the fourth topic: Contemporary applications of consensus The approach followed, the incomplete induction approach, and the descriptive approach.

\section{Results:}

1) The consensus that is considered by some scholars of the foundations, which is the consensus of all the nation in an era of the ages on one of the rulings is the argument and evidence if it could happen, it does not contradict the scholars, but its occurrence is not possible in any case.

2) The majority of the ummah agreed that this ummah does not meet without legal evidence, and its unanimity cannot be out of whim, or saying about God without knowledge, or without evidence; This is because the ummah is infallible, as saying about God without evidence is wrong.

3) The consensus may make the unanimous evidence definitive after it was originally speculative, such as the hadith of the Sundays that the nation unanimously agreed to accept and act upon.

Unanimity is a reason for preference; The text that is agreed upon is given precedence over others, and for this reason the fundamentalists have presented consensus over the Book and the Sunnah

Keywords: Authoritative, Consensus, Violators,Deduction , Definitive. 


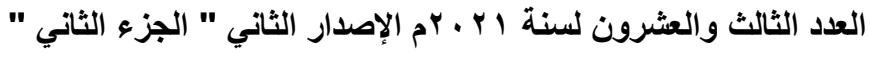

\section{مقدمة}

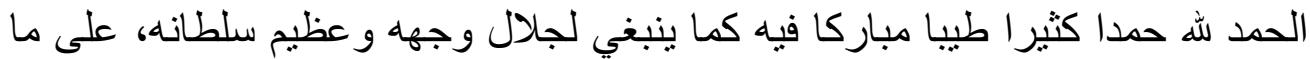

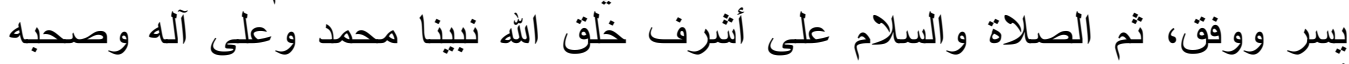
أجمعين ومن تبعهم بإحسان إلى يوم الدمان الدين.

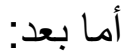
إن للإجماع أهمية كبرى باعتباره أحد أهم أربعة مصادر للأحكام الثر عية وجعلوه في

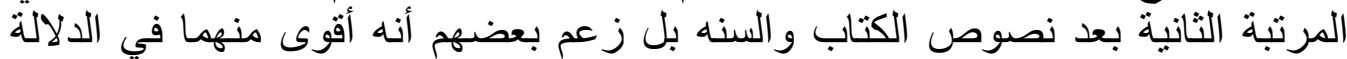

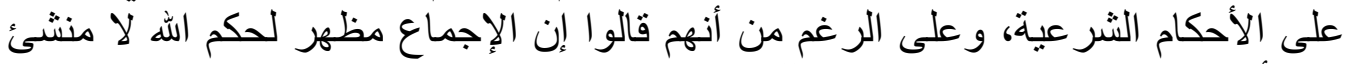

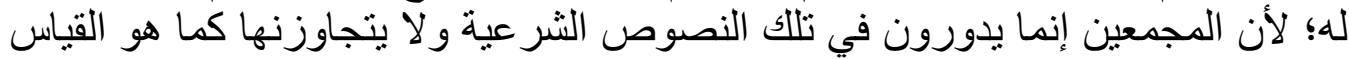
إلا أنه يعطي الأحكام الثرعية نورعا من القوة ويورث في نفوس الناس قناعة وحسن

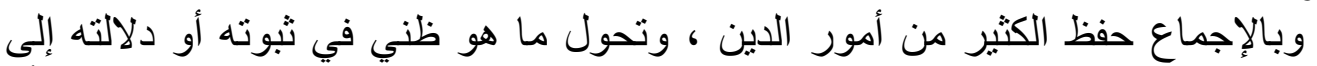

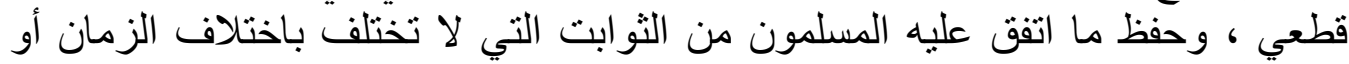

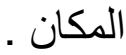

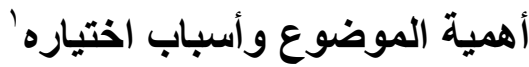

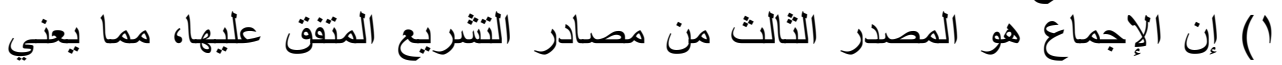
أهميته ومكانته في الفقه الإسلامي. إلهائ.

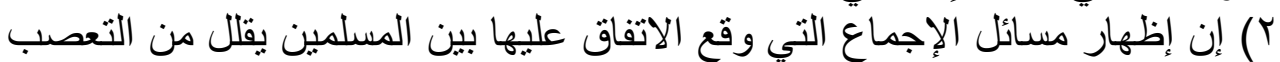

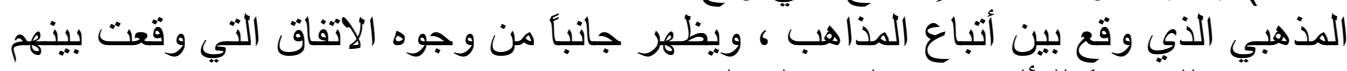
؛ فيكون ذللك سبباً للتأليف بين قلوب التباع المسلمين .

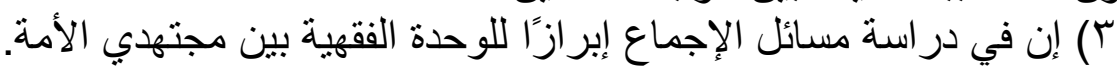

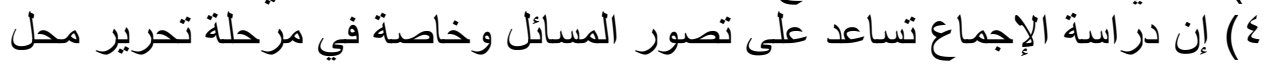

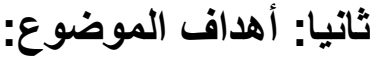

( ) بيان أن الإجماع حجة قاطعة لا يدخله النسخ.

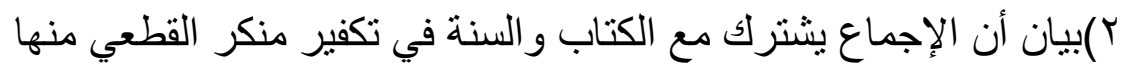

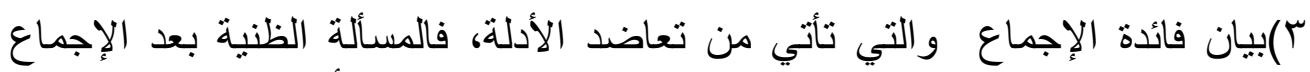
تصبح قطعية، وتخرج بذلك من دائرة الخلاف، وهذان هذا هو ما يسمى بأثر الإجماع في سنده. 
ع) بيان مسألة حجية الإجماع السكوتي والتي تلقي بظلالها على نقاش الباحثين في

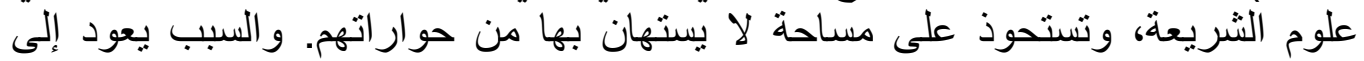

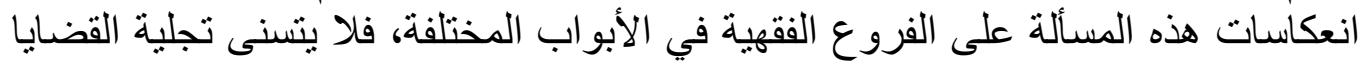

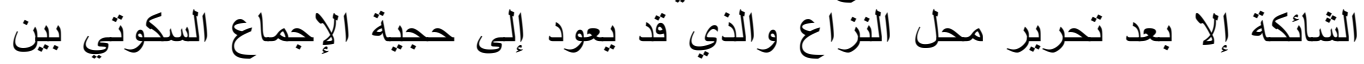

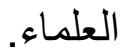

ثالثا: الاراسات السابقة للموضوع :

فلقد سعيت جاهدا للوقوف والاطلاع على بعض الجهود السابقة في هذا الموضوع؛ ومنها على سبيل المثال: (الإجماع في الثريعة الإسلامية، للاكتور رشدي عليان، بكلية الدعوة وأصول

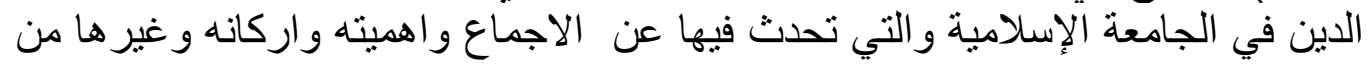

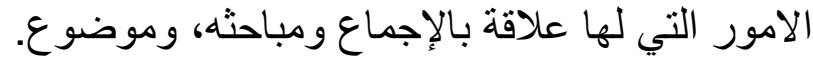

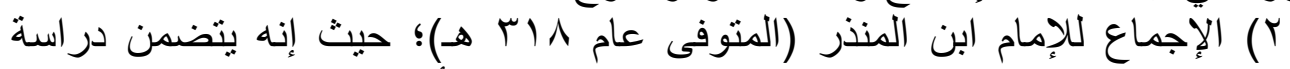

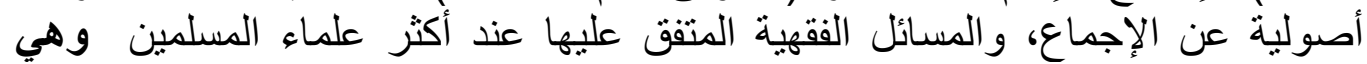

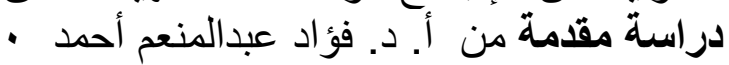
رابعا: منهج الدراسة في هذ فذا الموضوع:

يعتمد البحث -بعون الله- على عدة مناهج بحثية الهان الهمها:

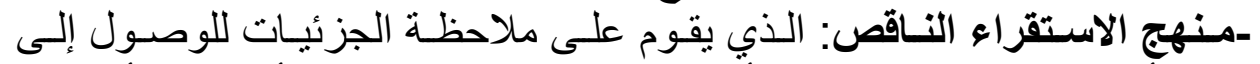

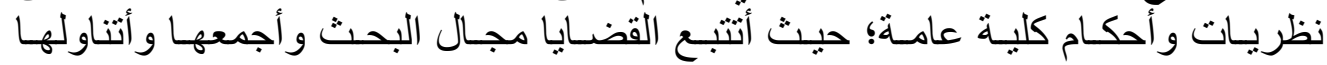
بالدراسة وفق المنهج التحليلي والاستة الاستنباطي.

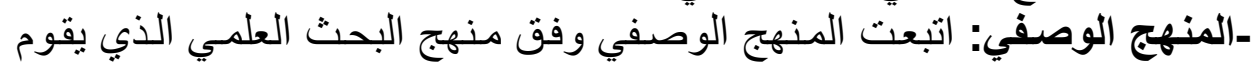

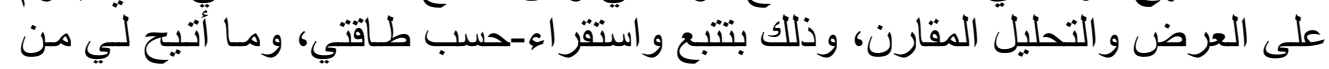
مصادر ومر اجع. - وأخيرًا المنهج الاستنباطي.

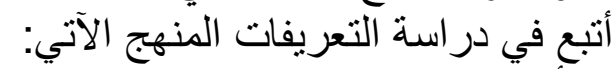
ـأقوم ببيان المصطلحات الواردة فئرات في الرسالة اللغوية منها والاصطلاحية، وذللك

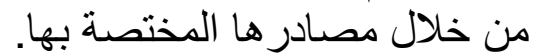

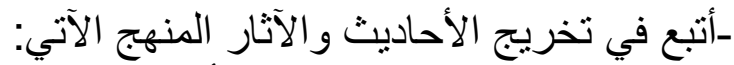

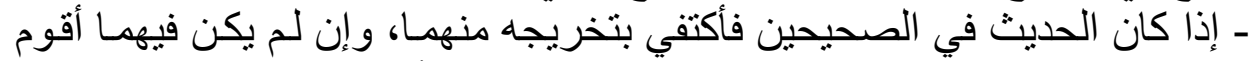
بتخريجه من كتب السنة، مع ذكر درجة الحديث من صحة أو أو ضعف، وذئ وذكر آر اء نقاد

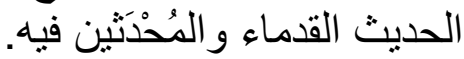




\section{خامسا: بالنسبة لخطة البحث:}

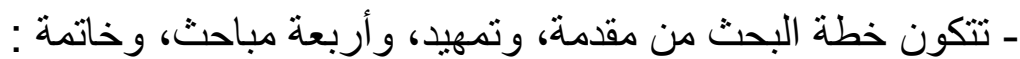

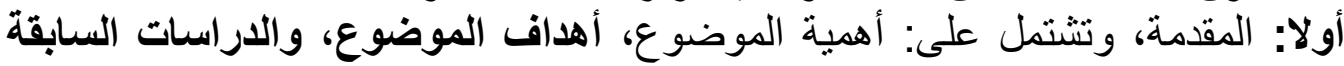

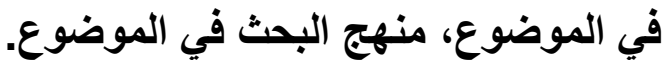
المبحث التمهيدي، تعريف الإجماع وحجيته وبيان منزلته

$$
\text { ويشتمل على أربعة مطالب: }
$$

المطلب الأول: تعريف الإجماع لغة والئة واصطلاحا.

المطلب الثاني- الدليل على الإجماع حجية الإجماع.

المطلب الثالثً - حجية الإجماع السكوتي.

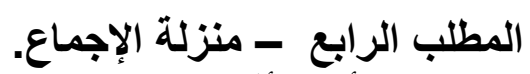

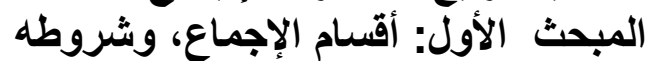

- 2 - ويشتمل على مطلبين :

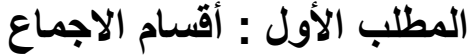

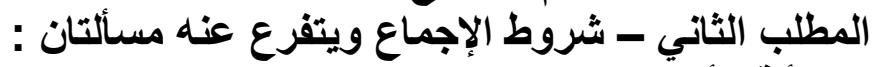

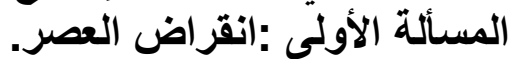

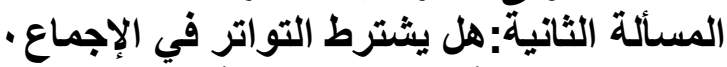

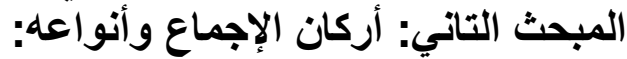

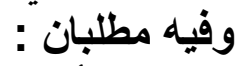

المطلب الأول ـ أركان الإجماع ، وفيه فرعان : الأول

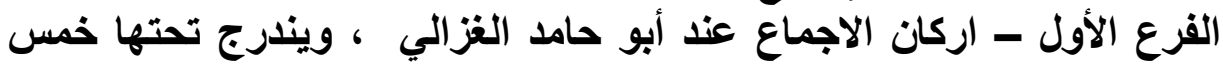

المسألة الأولى: ( إجماع أهل الحل والعقد )

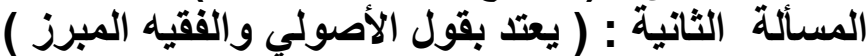

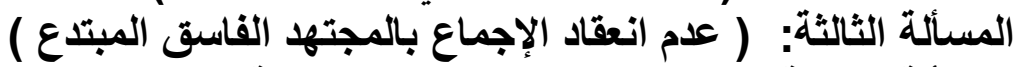

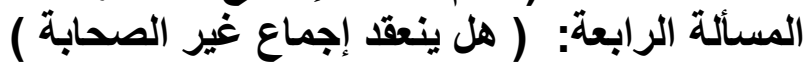

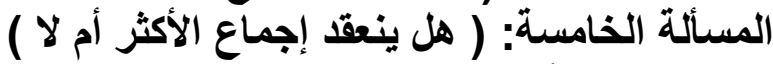

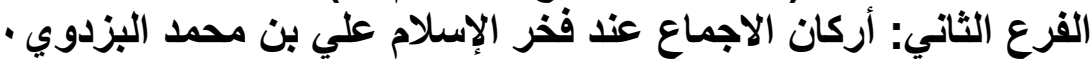

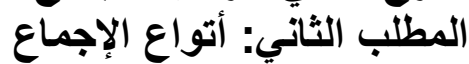

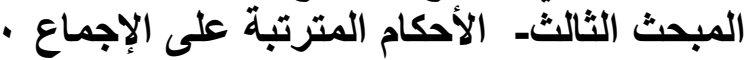

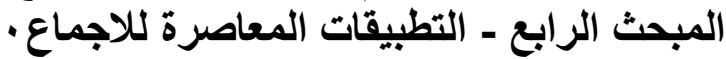
الخاتمة، وأهم النتائج والتوصيات ـ التطبات 


\section{الإبمث التمشهيدي}

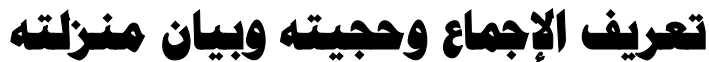

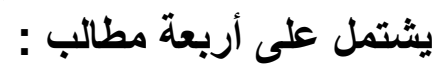

\section{المطلب الأول}

\section{تعربف الإجما ع لغة واصطلاما}

$$
\text { أولا - تعريف الإجماع لغة : }
$$

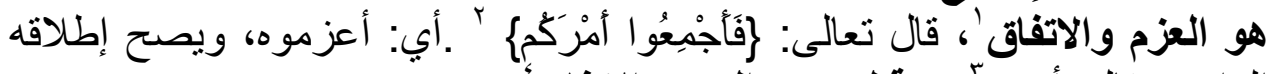

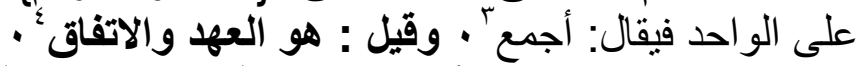

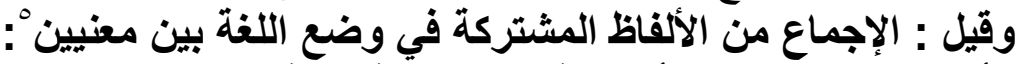

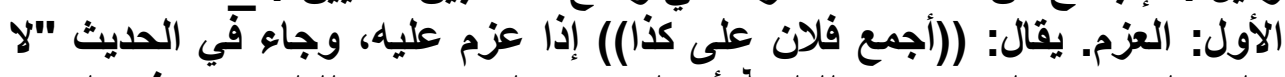

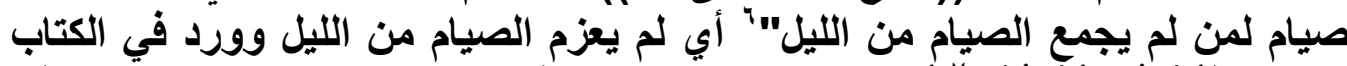

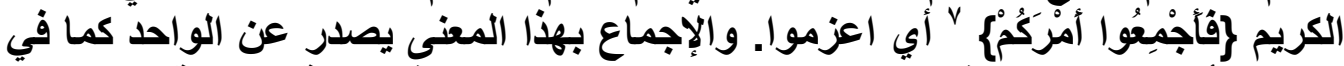
المثال الأول، وكما جاء في الحديث، ويصدر اعزي عن الجمع كما في الآية الكريمة.

'ـ تعليق مختصر على كتاب لمعة الاعتقاد الهادي إلى سبيل الرشاد ، المؤلف: محمد بن صالح بن

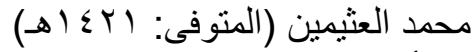
المحقق: أشرف بن عبد المقصود بن عبد الرحيم ـ الناشر : مكتبة أضواء السلف ، الطبعة: الطبعة الثالثة

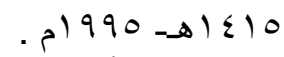

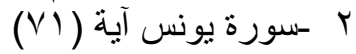

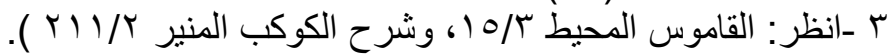

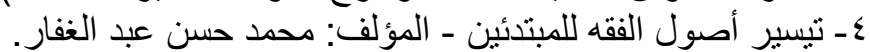

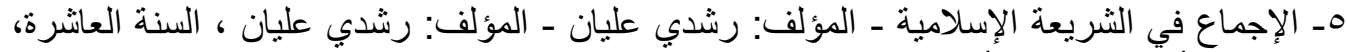

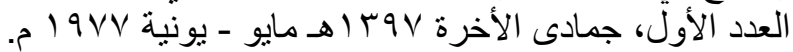

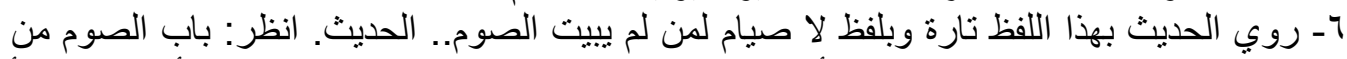

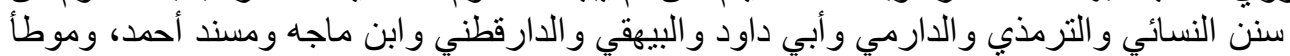




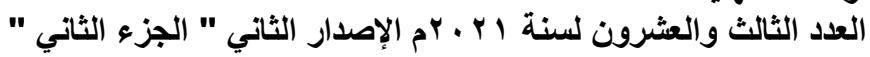

\section{الثاني: الاتفاق، يقال: ((أجمع القوم على كذا)) إذا اتفقوا عليه.}

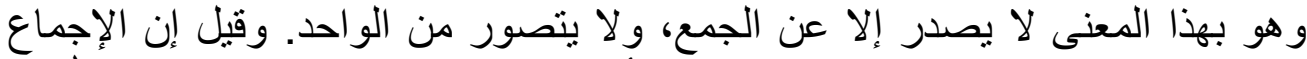

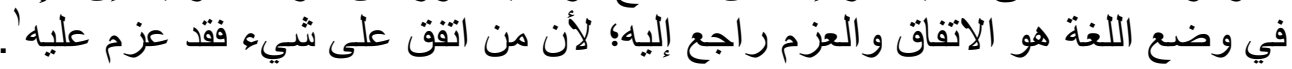

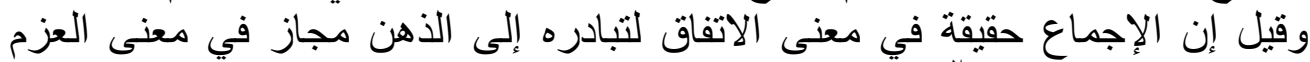

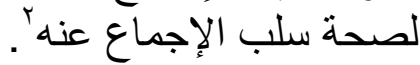

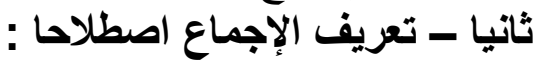

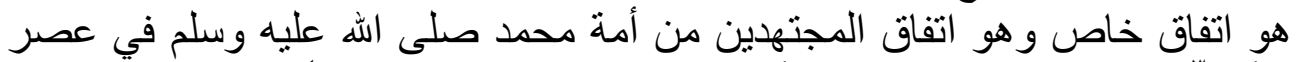

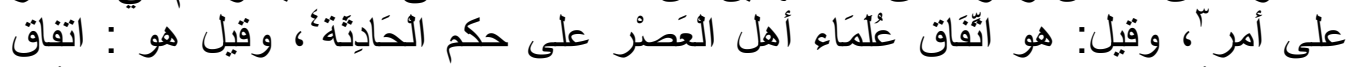

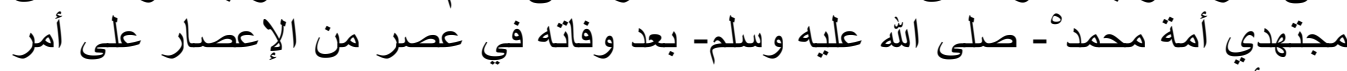

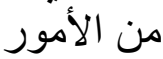
وقيل: هو "اتفاق مجتهدي عصر, من العصور من أمة محمد- صلى الله عليه وسلم بعد وفاته على أمر ديني . وقد اشتمل هذا التعريف على التى خمسة قيود:

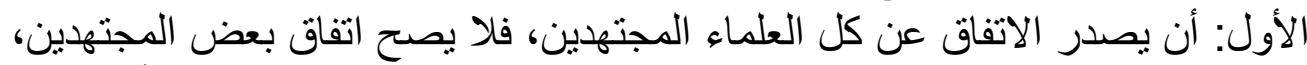

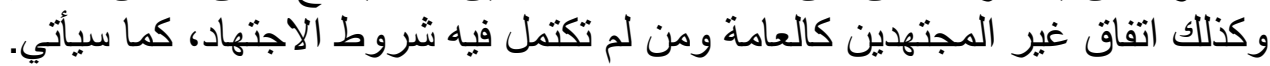

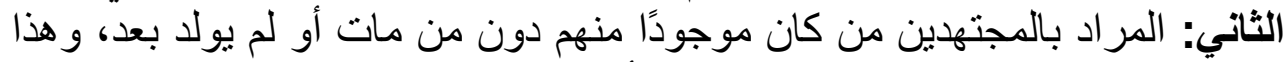

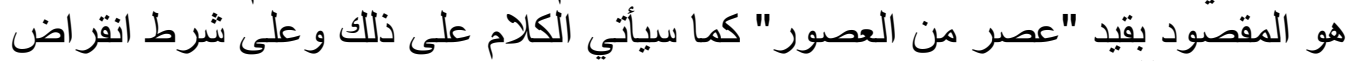

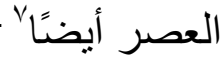
الثالث: لا بد أن يكون المجمعون من المسلمين، ولا عبرة بإجماع الأمم الأخرى غير المسلمة.

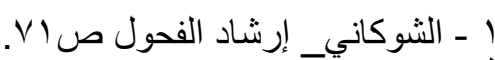

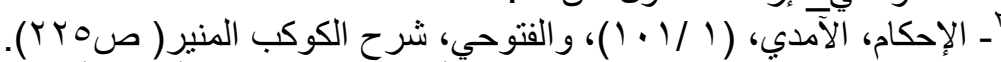

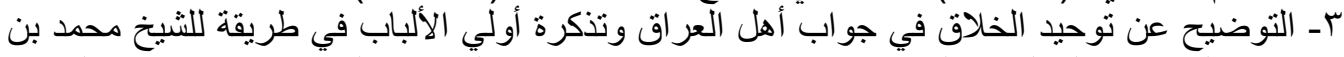

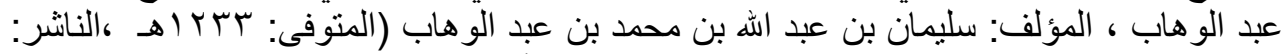

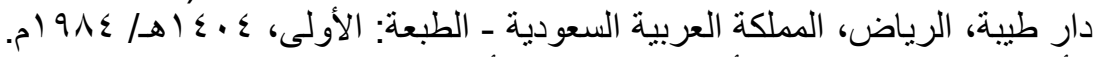

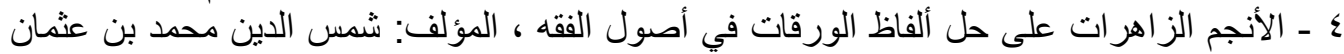

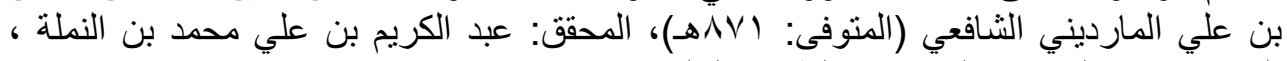

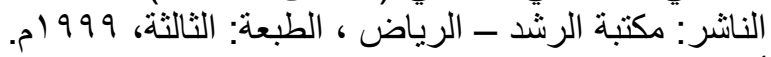

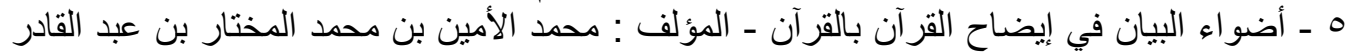

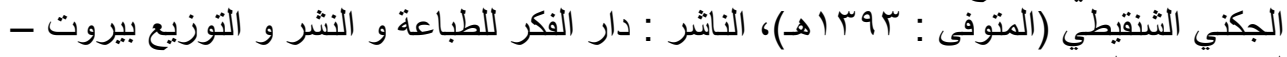

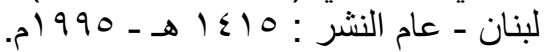

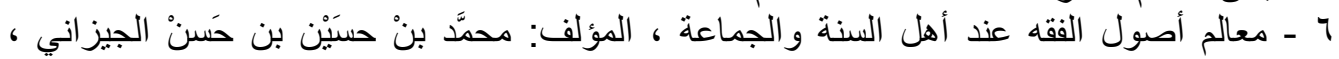

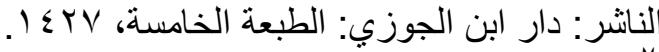

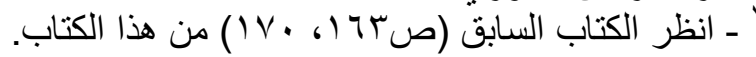

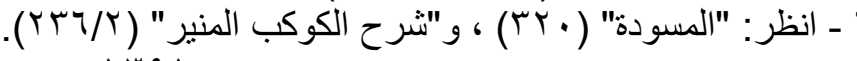


الر ابع: الإجماع إنما يكون حجة بعد وفاته - صلى الله عليه وسلم -، و لا يقع في حياته'. الخامس: أن تكون المسألة المجمع عليها من الأمور الدينية، ويخرج بذلك الأمور

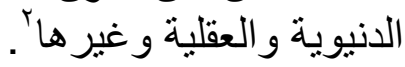

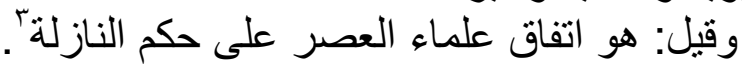

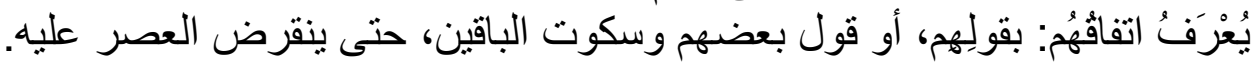

\section{المطالب النغانبي}

\section{الهليل على حبية الإجما ع .}

\section{- أولا الاليل من الكتاب :}

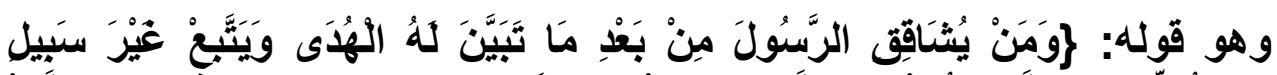

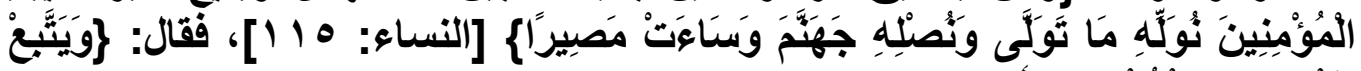

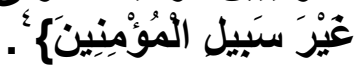

قال الشوكاني: "ووجه الدلالة من الآية: أن الله - تعالى- جمع بين مشاقة الرسول - فئل

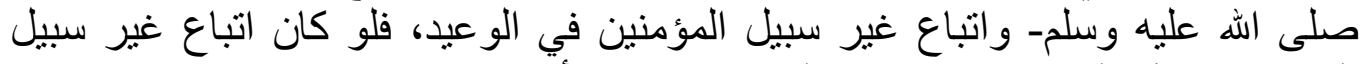

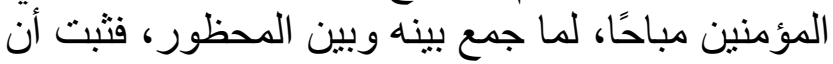

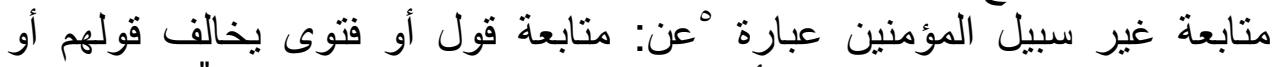

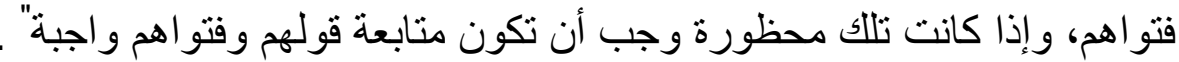

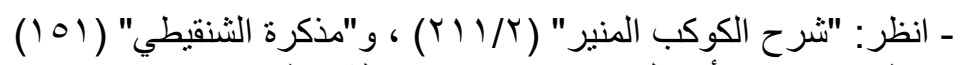

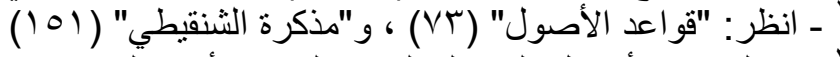

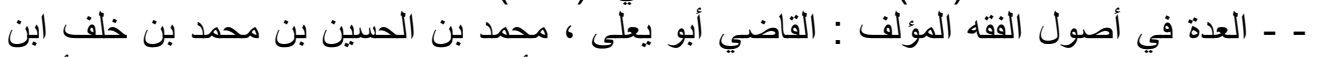

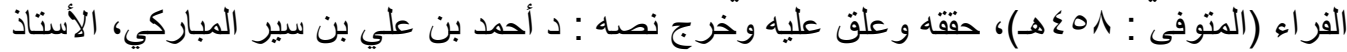

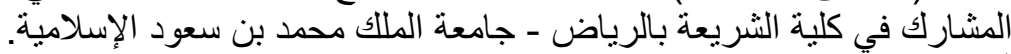

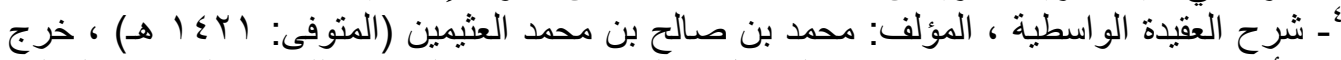

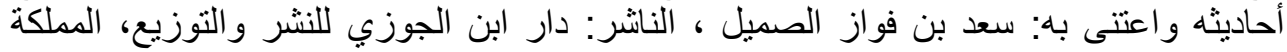

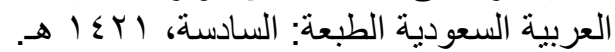

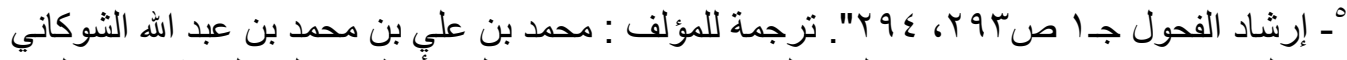

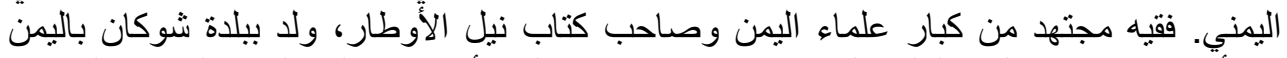

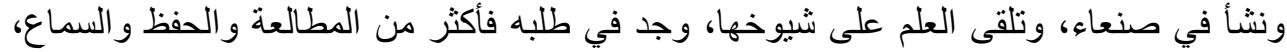

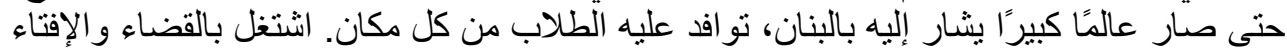

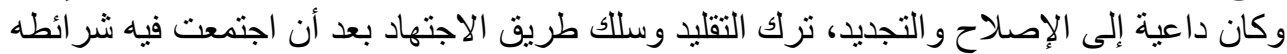

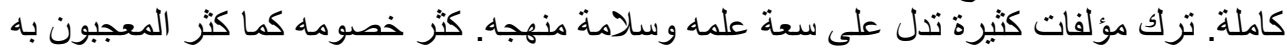

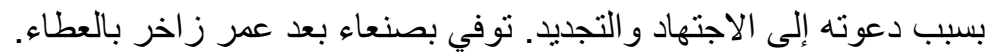

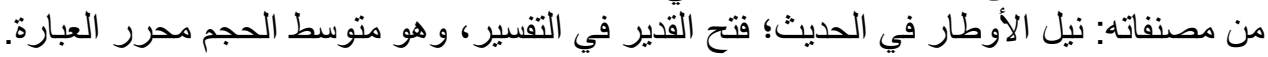


ثانيا الاليل من السنة:

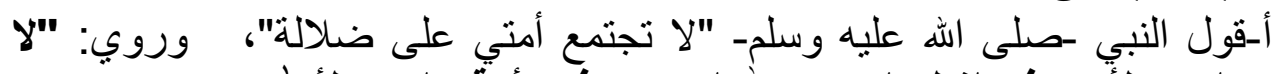

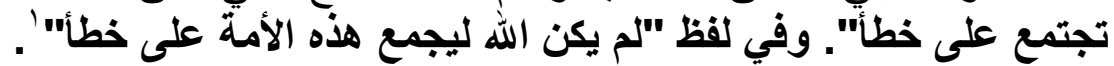

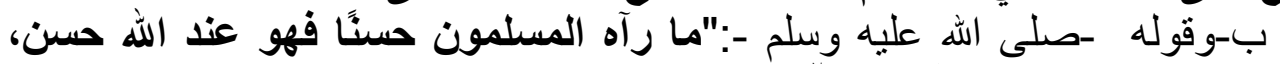
وما رأوه قبيحًا فهو عند الله قبيح"

ج- وقوله -صلى الله عليه وسلم-:"من فارق الجماعة شبرًا فقد خلع ربقة الإسلام من عنقه" د- وقوله -صلى الله عليه وسلم-: "من فارق الجماعة مات ميتة جاهلية"؛

\section{وجه الالالة من هذه الاحاديث من ثلاثة وجوه :}

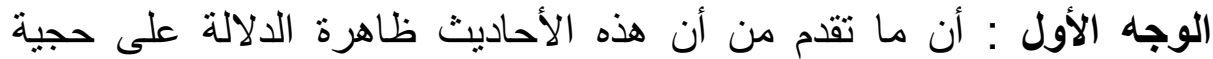

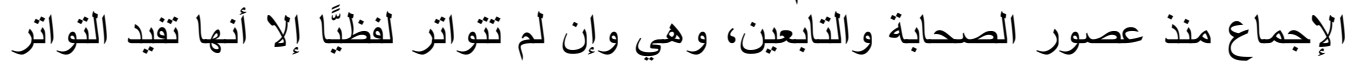

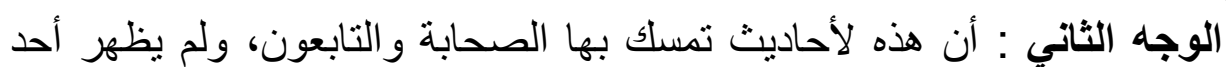
المعنوي الإعماع

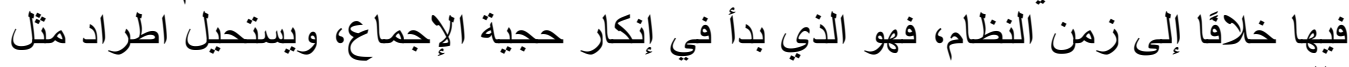

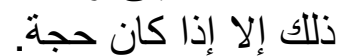

ا ـ هذا الحديث روي بألفاظ مختلفة مرفو عًا من حديث عبد الله بن عمر -رضي الله عنهما- أخرجه عنه إله

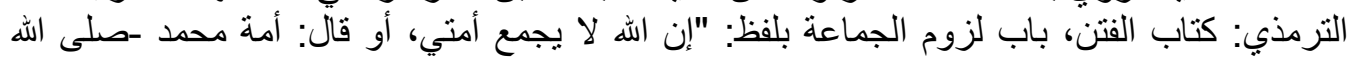

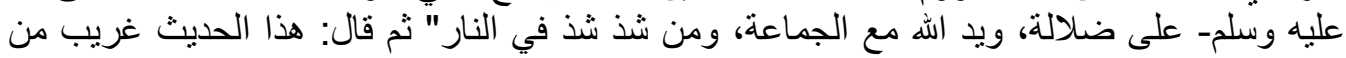

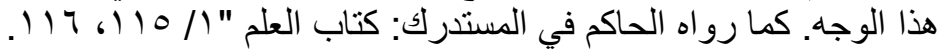

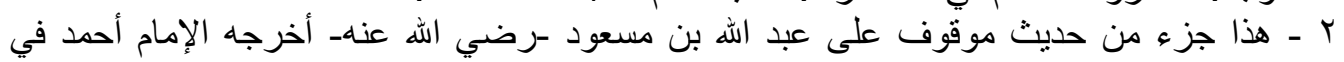

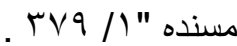

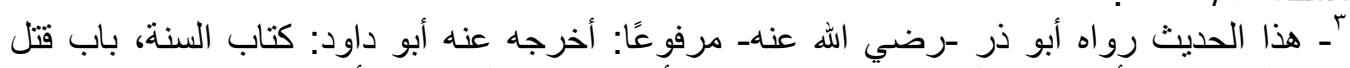

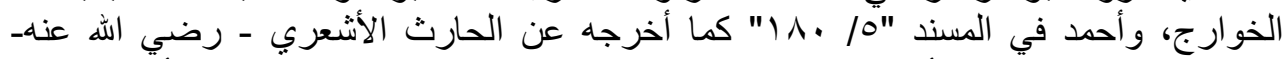

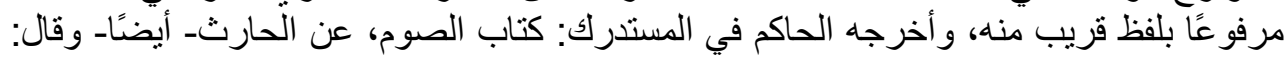

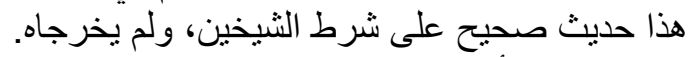

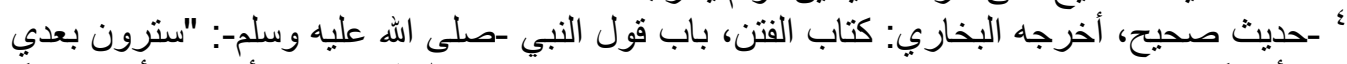

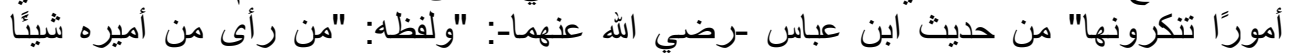

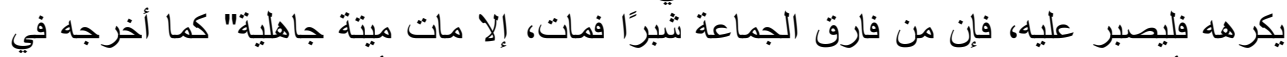

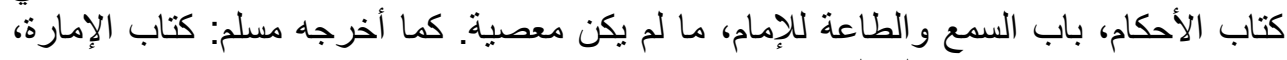
باب وجوب ملازمة جماعة المسلمين.

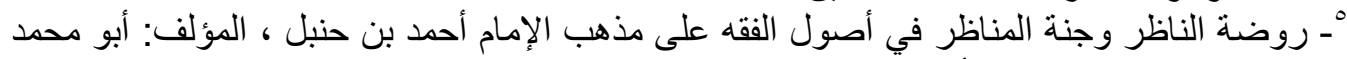

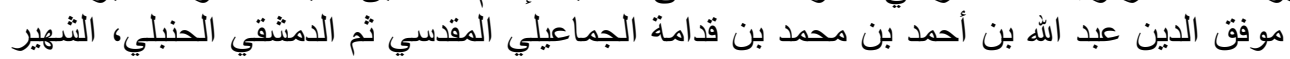

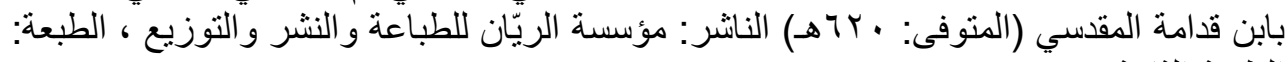

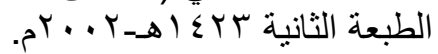




\section{حجية الإجماع}

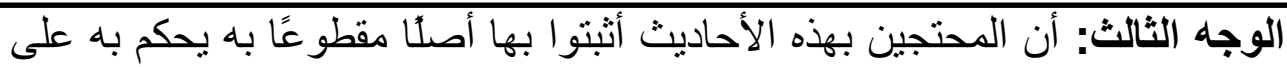
كتاب الله تعالى وسنة رسوله -صلى الله عليه وسلم- فلا بد وأن يكون مستندًا، إلى دليل بله الهيل قطعي.

\section{المطاب النغالث \\ هبية الإجما ع السكوتيكا}

أو لا - أقو ال العلماء في هذه المسألة :

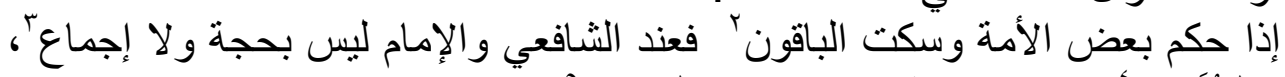

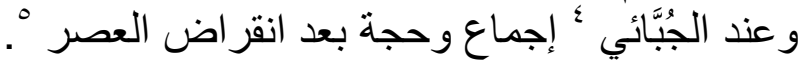

'ـ جزء من شرح تنقيح الفصول في علم الأصول المؤلف: أبو العباس شهاب الدين أحمد بن إدريس بن

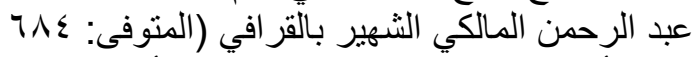

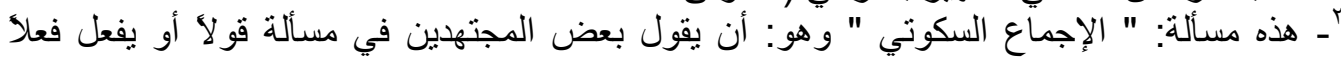

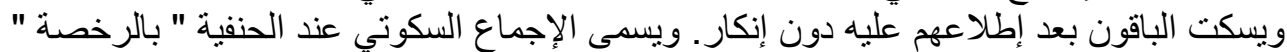

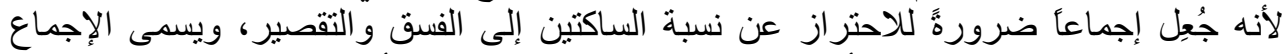

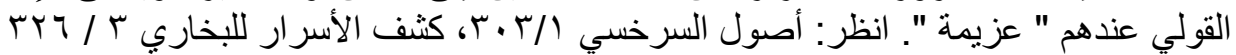

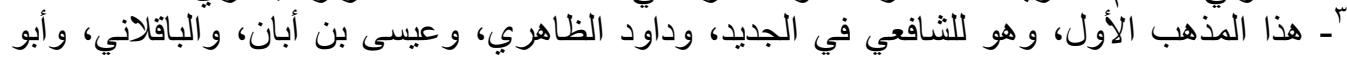

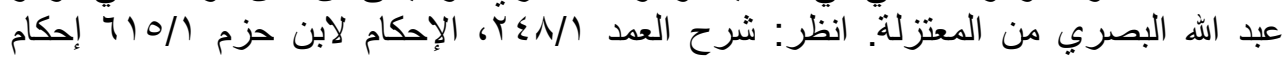

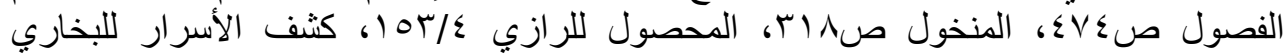
س $\leqslant 7 r_{-} \leqslant 0 T / 7$

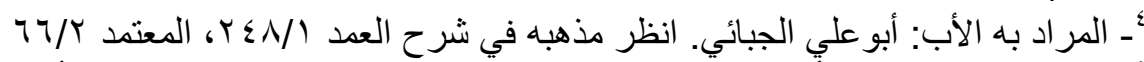

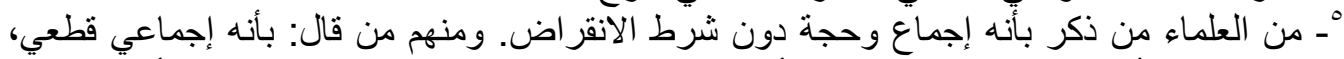

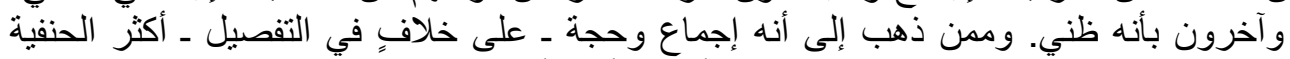

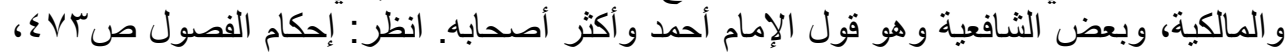

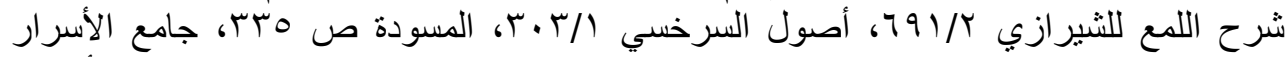

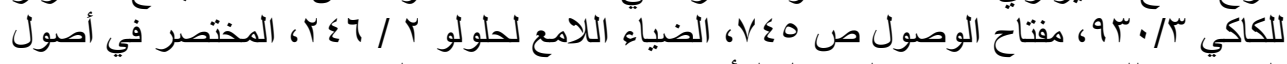

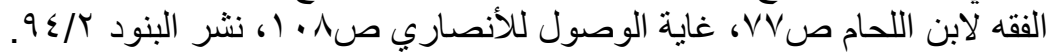

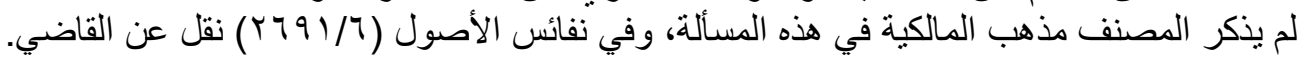


مجلة كلية الثريعة والقانون بتفهنا الأثراف ـ دقهلية

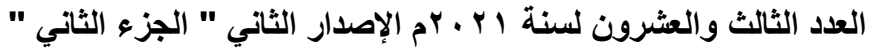

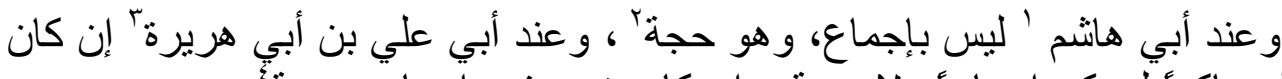

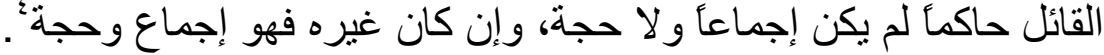

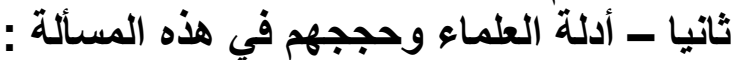

حجة الأول: أن السكوت قد يكون لأنه في مهلة النظر، أو يعتقد أن قول خصمه مما

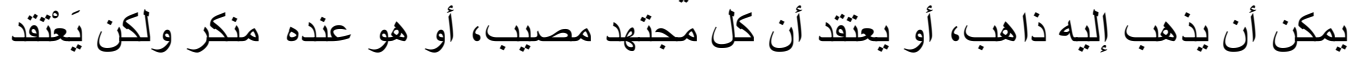

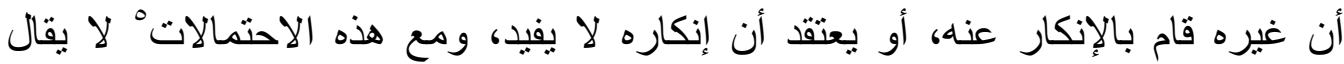

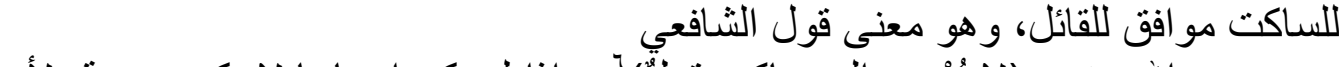

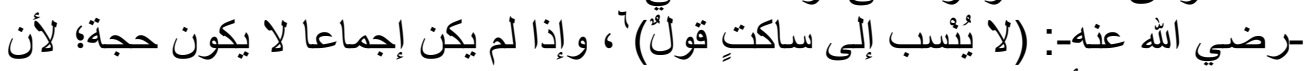

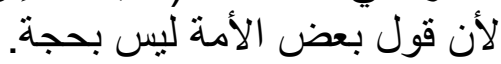

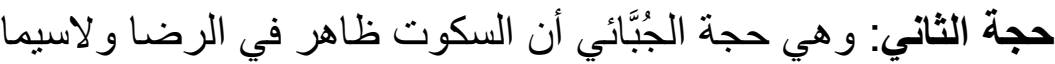

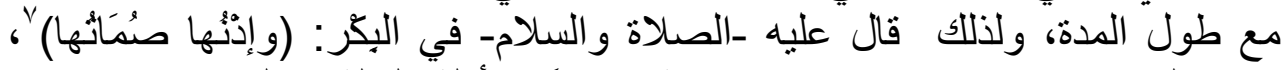

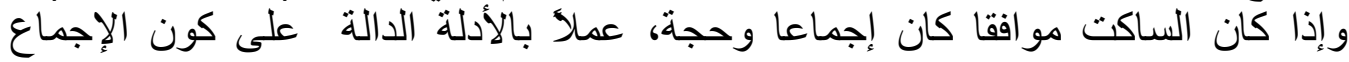

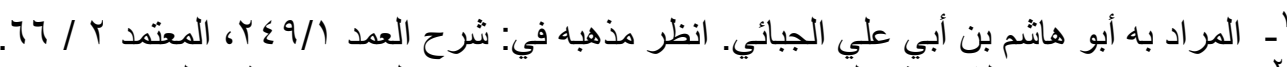

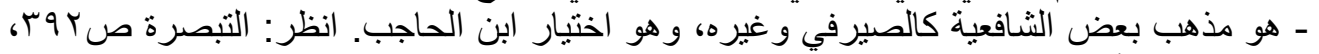

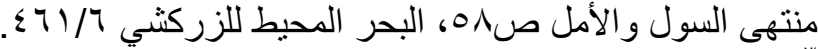

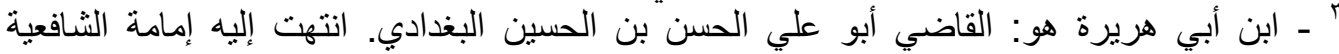

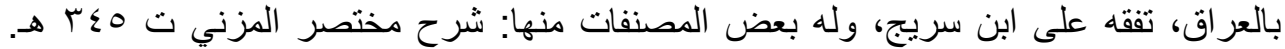

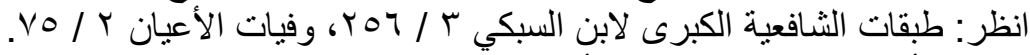

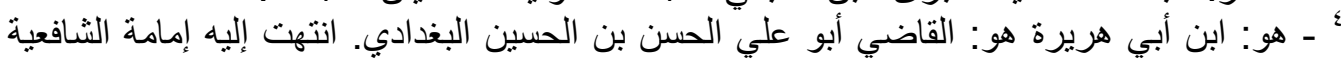

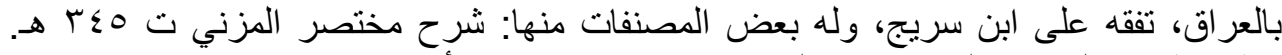

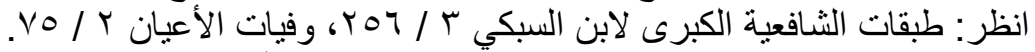

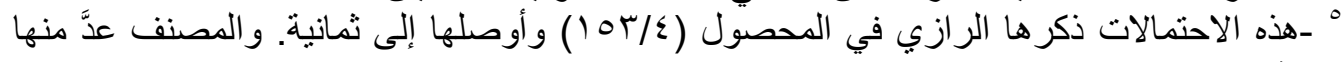

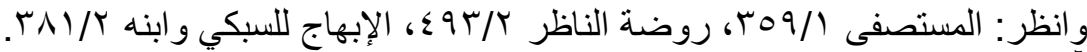

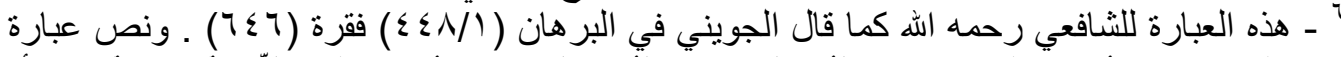

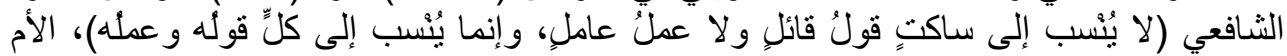

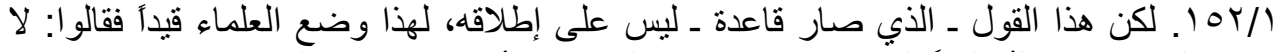

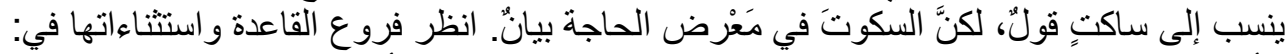

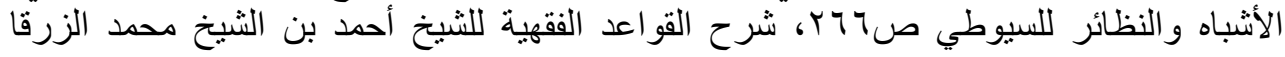

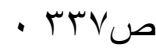

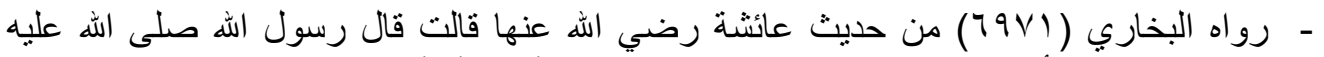

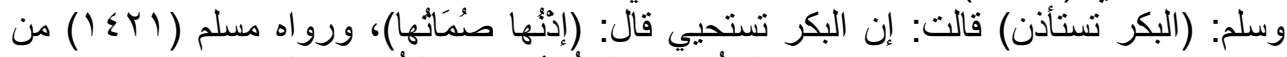

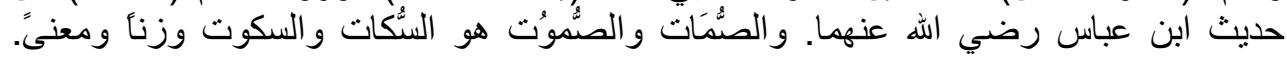
انظر : لسان العرب مادة " صمت ". 
حجة الثالث: وهو حجة أبي هاثم أنه ليس إجماعأ لاحتمال السكوت ما تقدم من وإنه

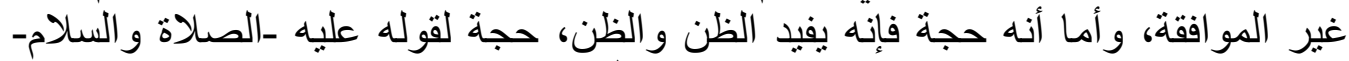

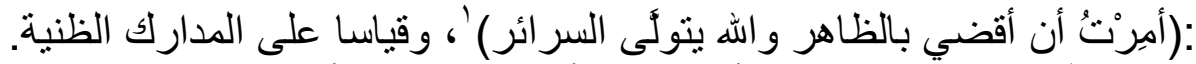

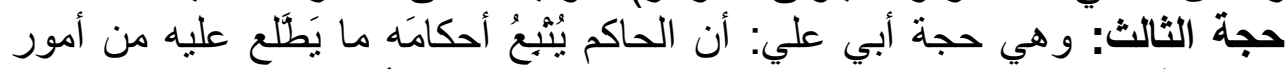

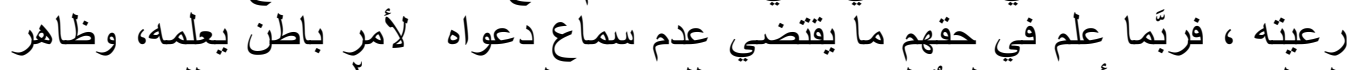

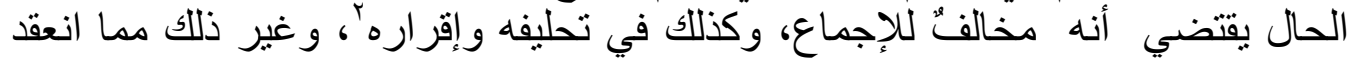

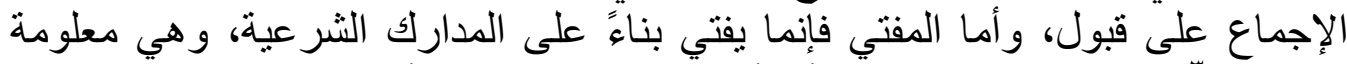

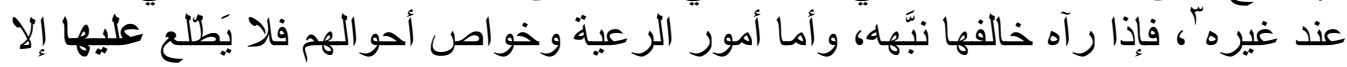

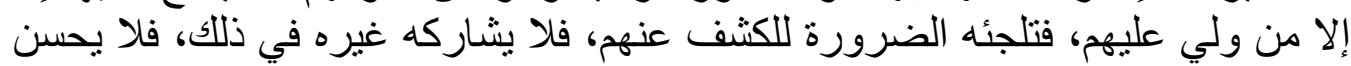

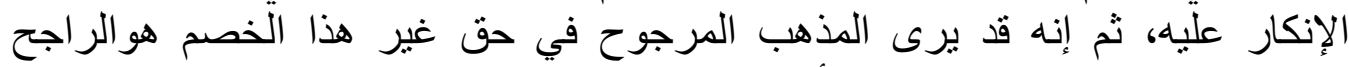

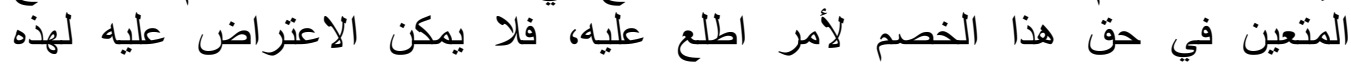
الاحتمالات.

\section{المطلب الرابـر}

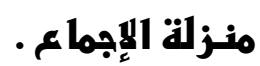

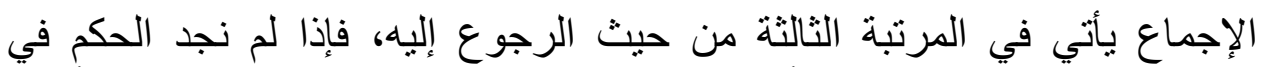

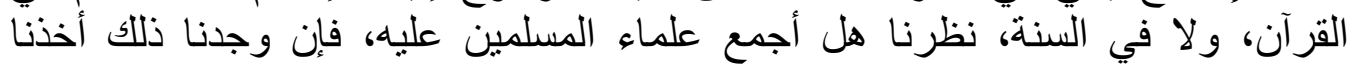

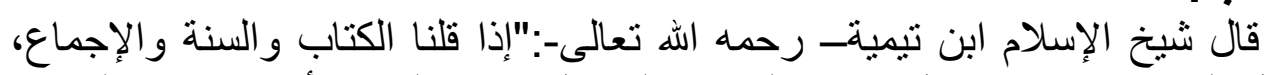

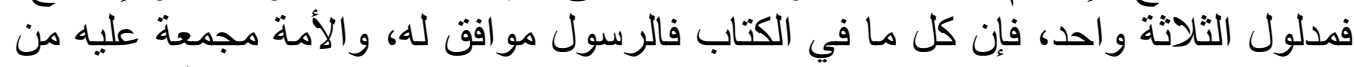

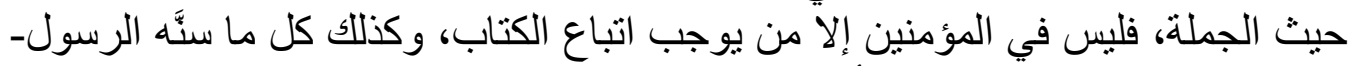

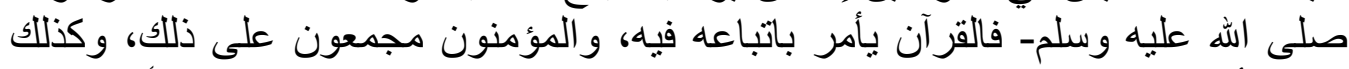

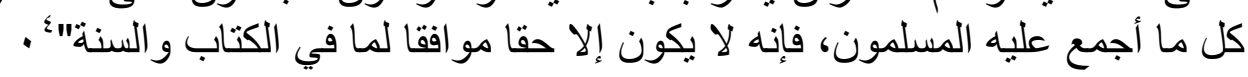

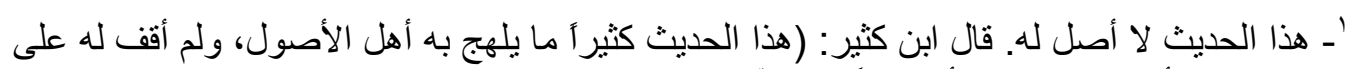

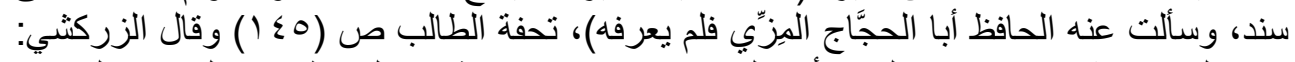

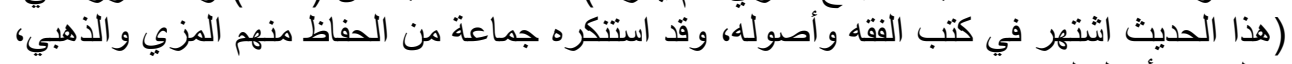
وقالو ا: لا أصل لهله.

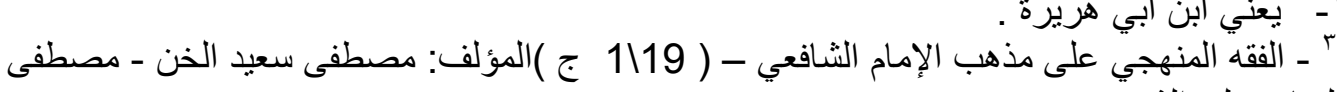




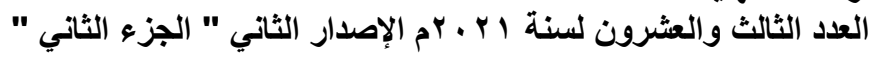

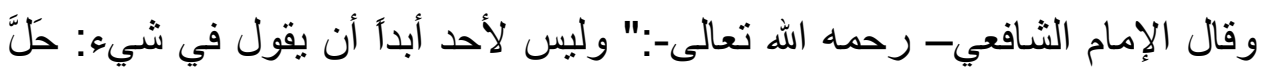

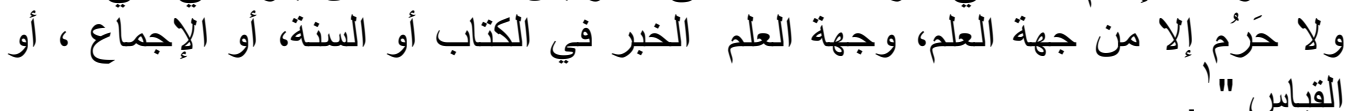

والإجماع حجة قوية في إثبات الأحكام الفقهية ومصدر يلي السنة في المرتبة ـ وددليل

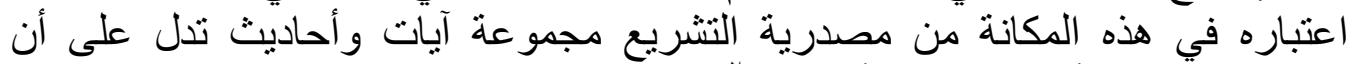

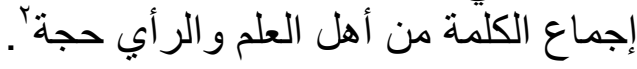

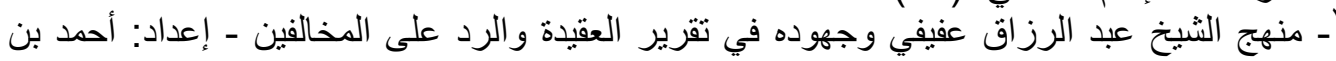

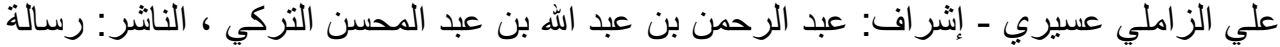
مقدمة لنيل درجة الماجستير في العقيدة والمذاهب المبل المعاصرة - كلية أصول الدين الدين - جامعة الإمام

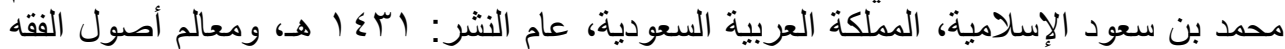

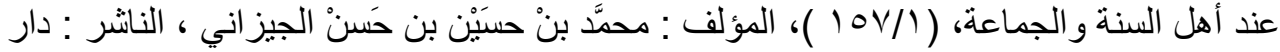

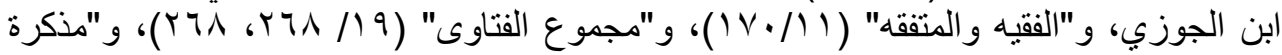

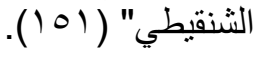




\section{المبمث الأول

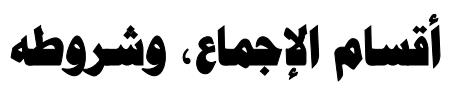

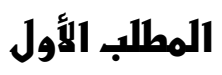

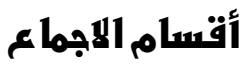

وفيه مطلبان :

ينقسم الإجماع إلى عدة تقسيمات باعتبار ات مختلفة:

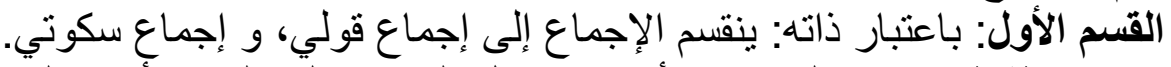

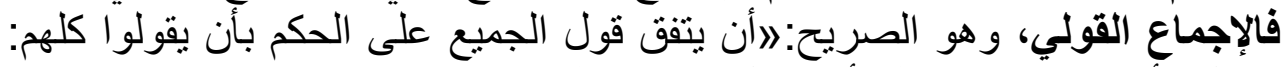

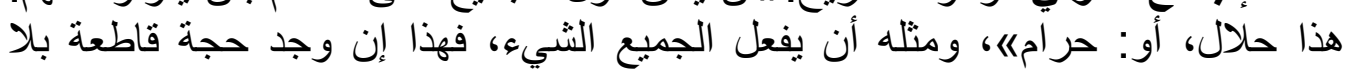
والإجماع السكوتي أو الإقراري، هو: "إن يشتهر القول أو الفعل من البعض فيسكت

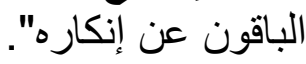
ومثله الإجماع الاستقر ائي، وهو: "إن ثُتقر أ أقو ال العلماء في مسألة فلا يُعلم خلاف وقذ اختلف العلماء في حجية الإجماع السكوتي، فبعضهم اعتبره حجة قاطعة،

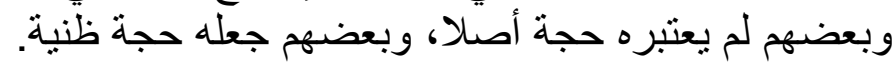

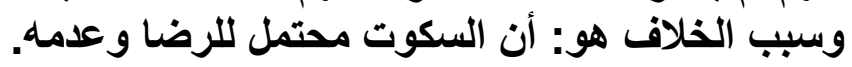

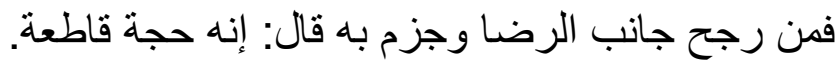

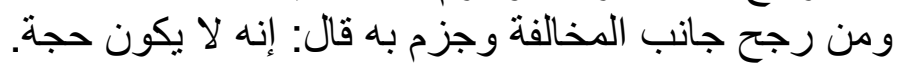

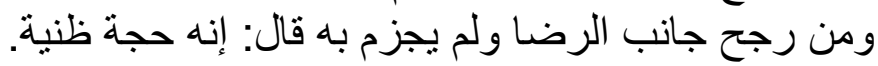

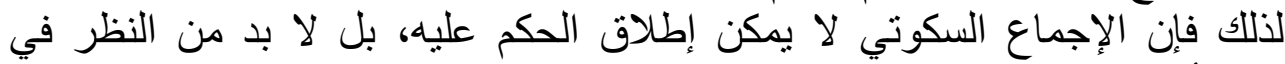

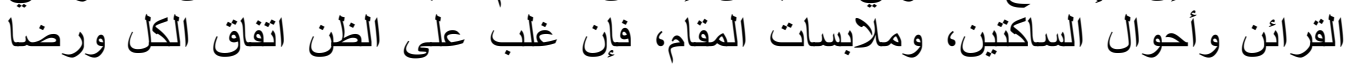

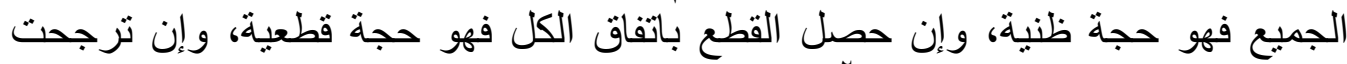

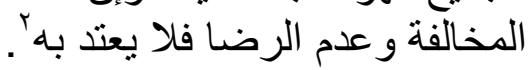

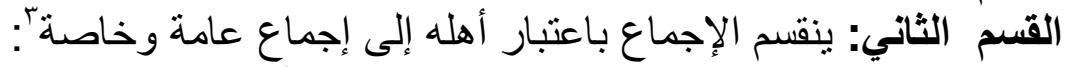

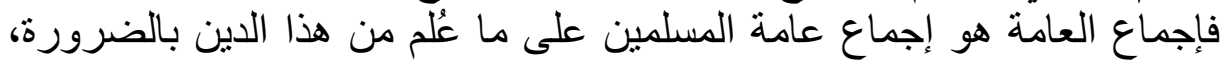

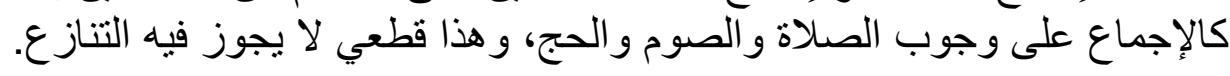

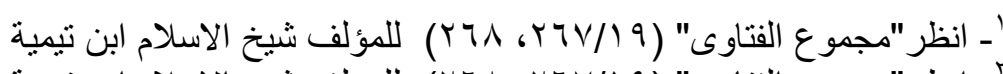

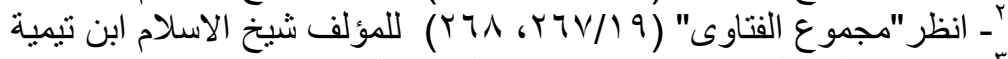

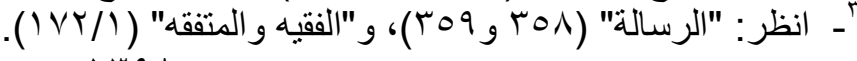




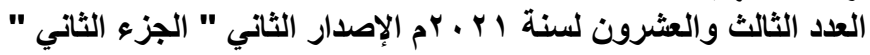

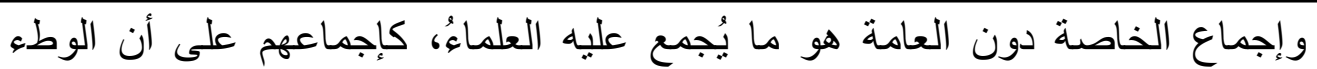

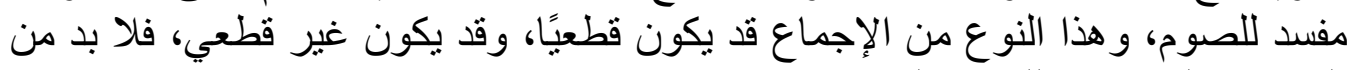
الوقوف على صفته للحكم عليه. القسم الثالثـ- ينقسم الإجماع باعتبار عصره إلى إلى: إجماع الصحابة رضي الله عنهم، و إجماع غير هم' فإجماع الصحابة يمكن معرفته والقطع بوقوعه، ولا نزاع في حجيته عند القائلين بحجية الإجماع. و أما إجماع غير الصماع إعابة ممن بعدهم فإن أهل العلم اختلفوا فيه من حيث إمكان

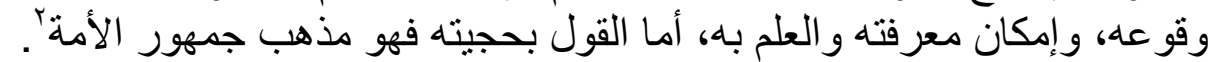

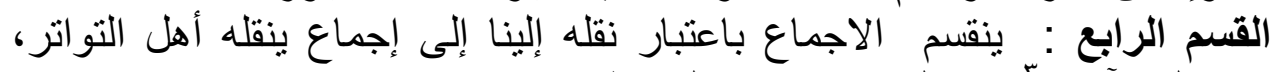
و إجماع ينقله الآحاد 'وكلا القسمين يحتاج إلى نظر من جهتين:

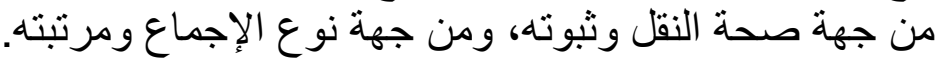

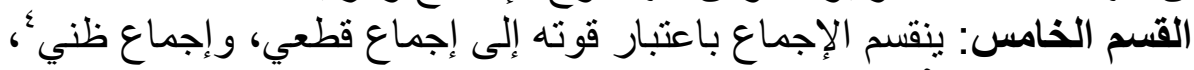

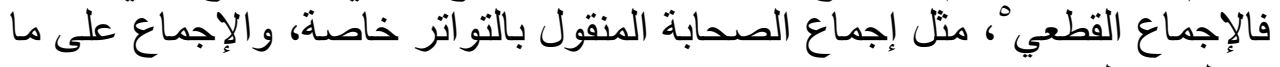
عُلم من الدين بالضرورة. و الإجماع الظني كالإجماع السكوتي الذي غلب على الذي الظن فيه اتفاق الكل.

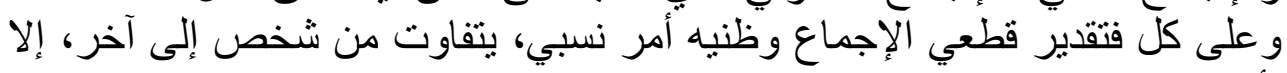
أن الأمر المقطوع بـه في قضية الإجماع شيئيان:

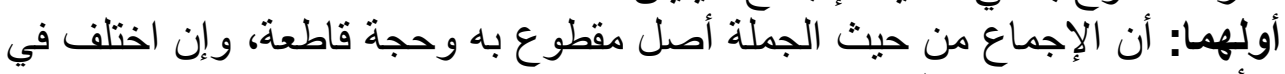
بعض أنو اعه وبعض شروان. وثانيهما: أن بعض أنواع الإجماع لا يقبل فيها نزاع؛ بل هي إجماعات فطعية كما تقدم التمثيل لذلك آنقًا.

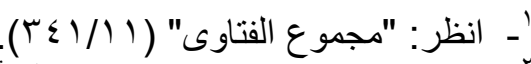

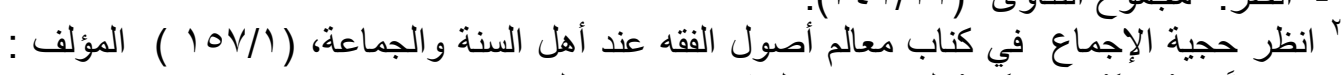

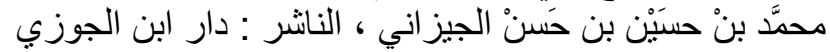

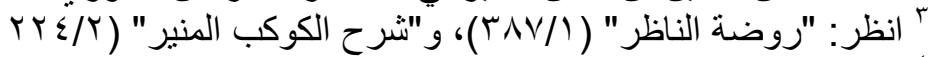

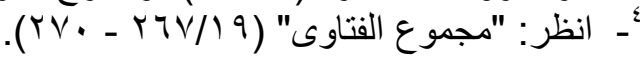

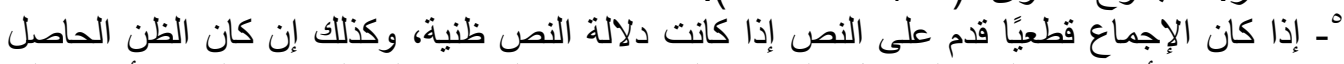

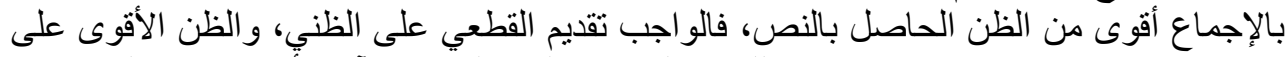

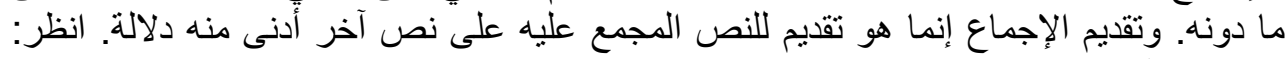




\section{المطلب الفانبي}

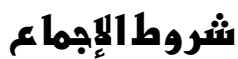

الشرط الأول - أن يثبت بطريق صحيح: وهو أن يثبت بطريق صحيح بأن يكون إما

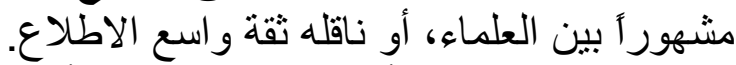

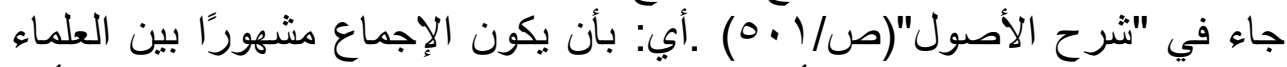

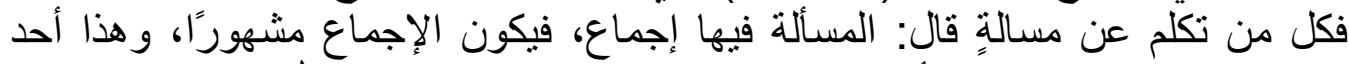

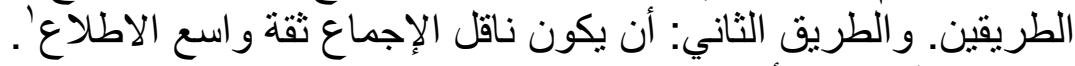

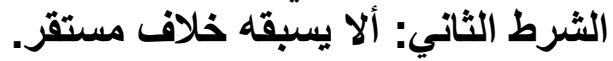

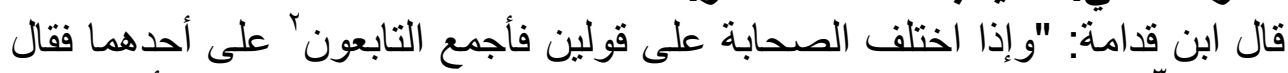

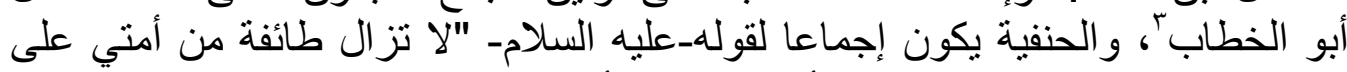

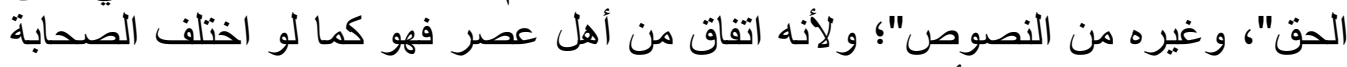
على قولين ثم اتفقو العلى أحدهما.

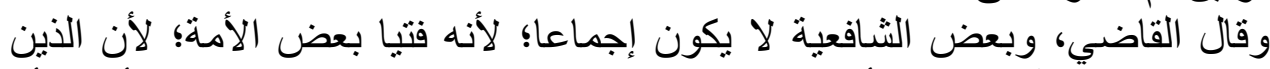

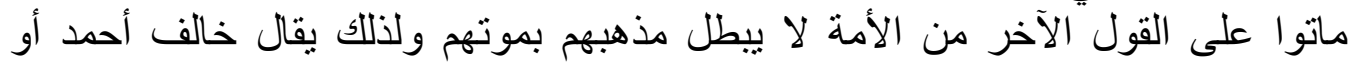

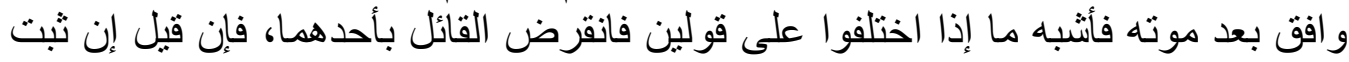

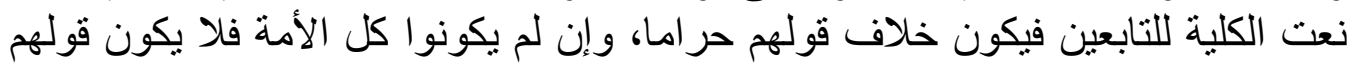

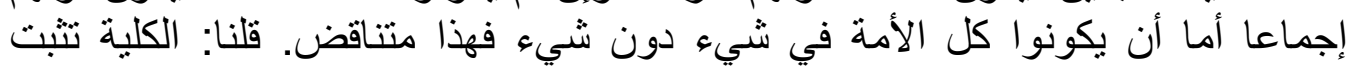

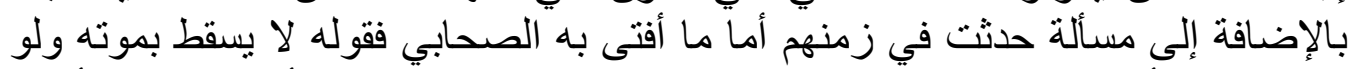

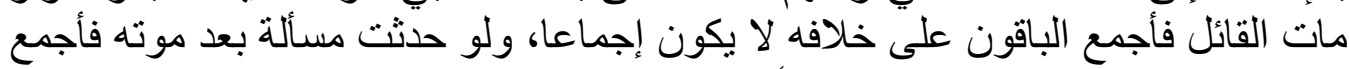

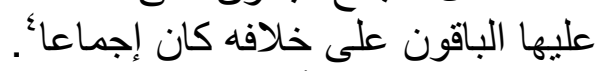
ومن وجه آخر أن اختلاف الصحان إحماعة إعلة على قولين اتفاق منهم على تسويغ الأخذ بكل

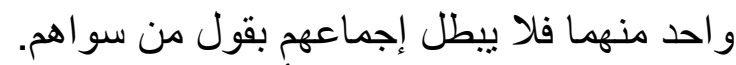

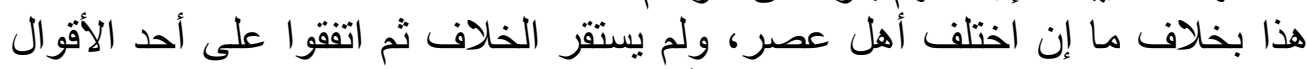
فهنا يصح الإجماع لاتتفاء الخلاف، واتفاق أهل العصر على الته فول واحد.

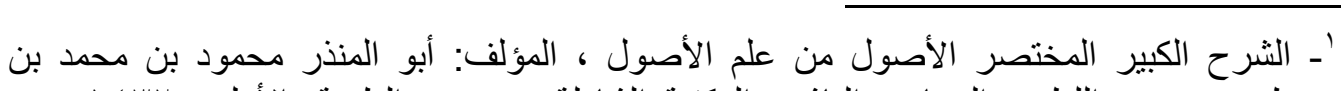

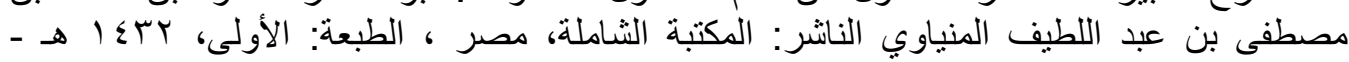

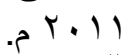

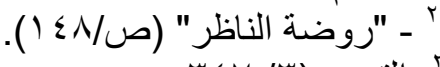

$$
\begin{aligned}
& \text { r }
\end{aligned}
$$

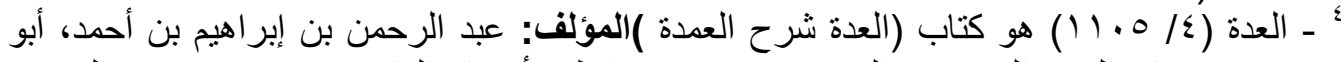

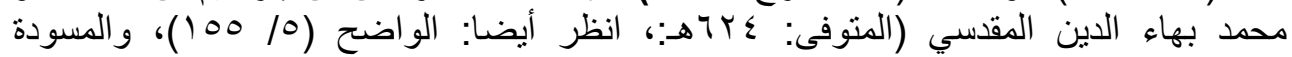

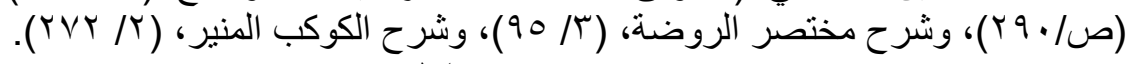




\section{المسألة الأولى: انقراض العصر.}

المقصود بانقراض العصر الفرافي هو موت جميع من هو من أهل الاجتهاد في وقت نزول الحادثة بعد اتفاقهم على حكم فيها. و عدم اشتراط انقراض العصر هي الرواية التي أومأ إليها أحمد، وهي اختيار

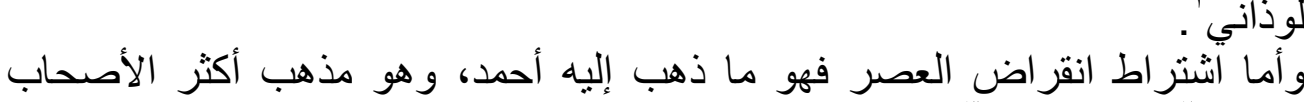

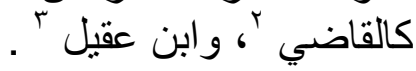

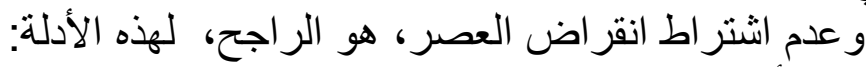

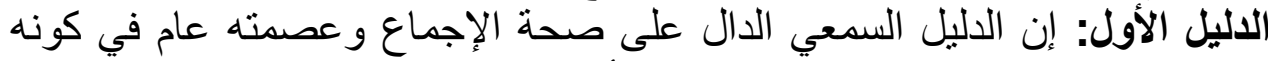

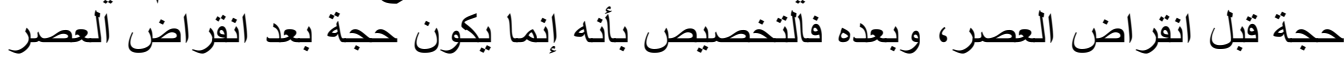
تحكم من غير دليل.

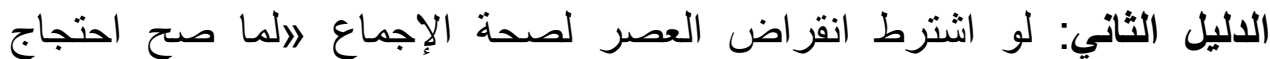

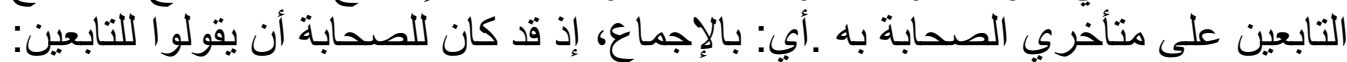

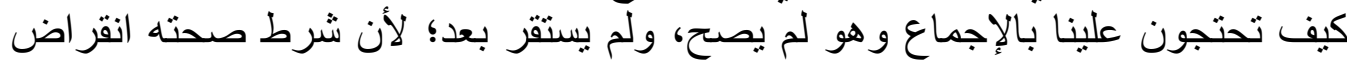

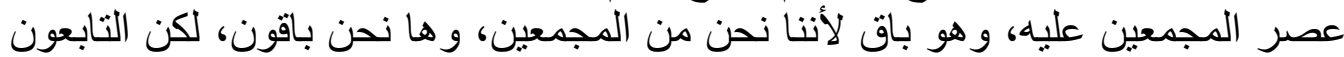

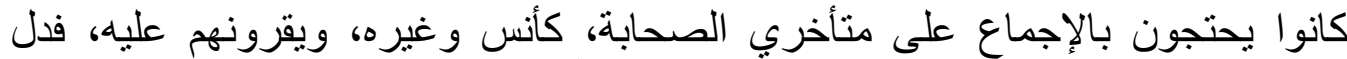

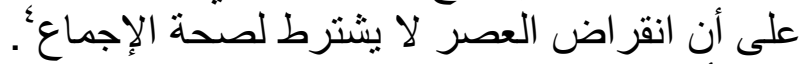
وأيضا: فإن الصحابة كانوا يحتجون بالإجماع بعضهم على بعض، و وعلى بعض

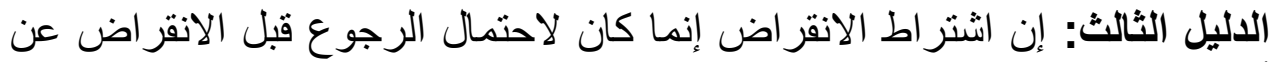

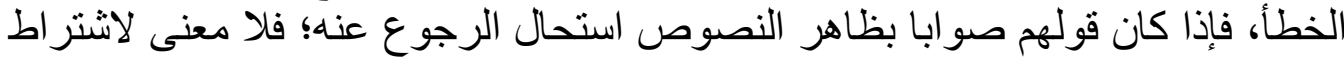

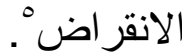
المسالة الثانية: هل يشترط التواتر في الإجماع:

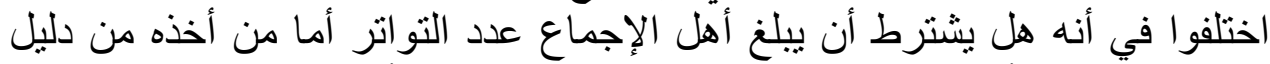

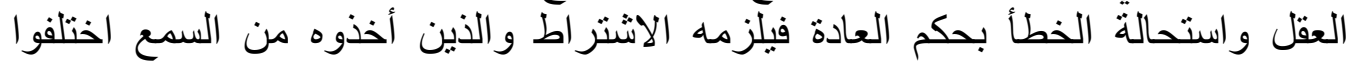

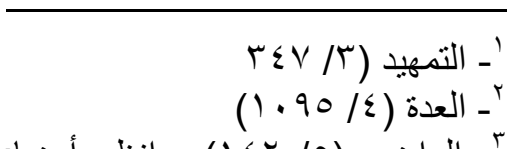

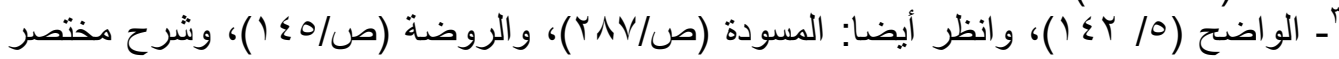

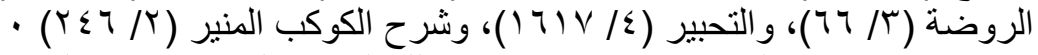

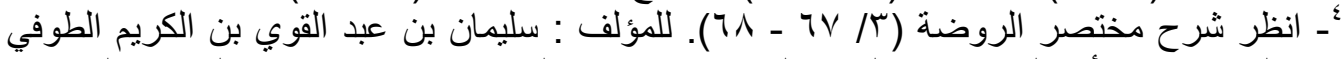

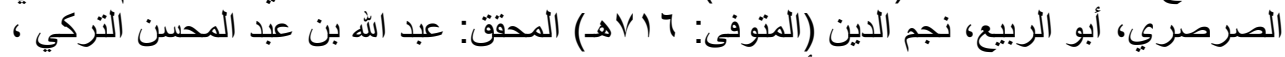

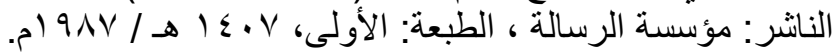

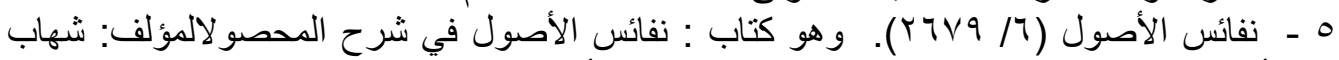

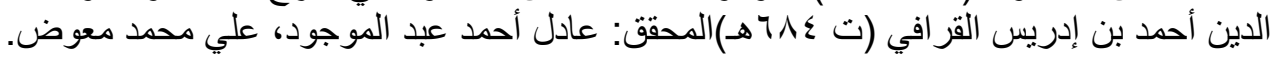


فمنهم من شرط؛ ذلك لأنه إذا نقص عددهم فنحن لا نعلم إيمانهم بقولهم فضلا عن غيره و هذا فاسد من وجهين' أحدهما: أنه بعلم إيمانهم لا بقولهم لكن بقوله - صلى الله عليه وسلم- لا نز ال طائفة من أمتي على الحق حتى يأتي أمر الله، وحتى يظهر الاجهال فإذاذا لم يكن على على وجه

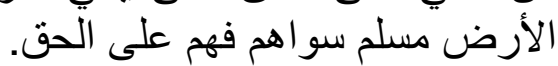
الوجه الثاني: أنا لم نتعبد بالباطن، وإلى وإنما أمة محمد من آمن بمحمد -صلى الله عليه

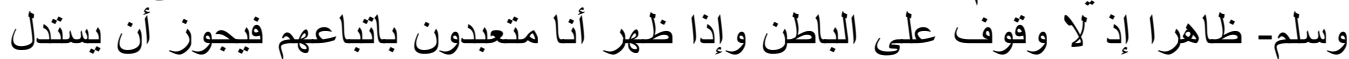

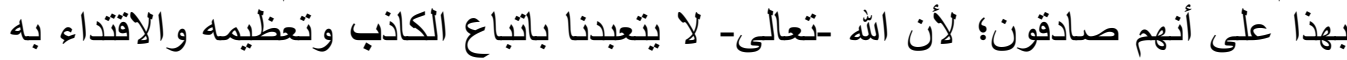

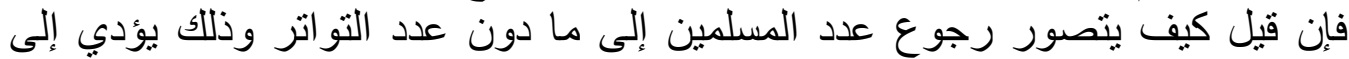

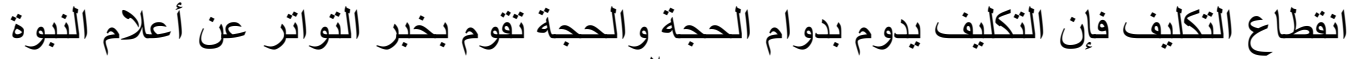

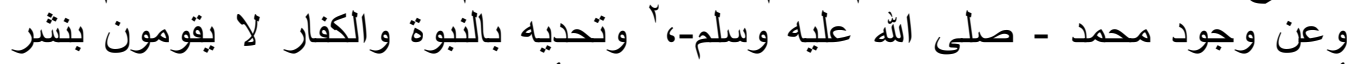

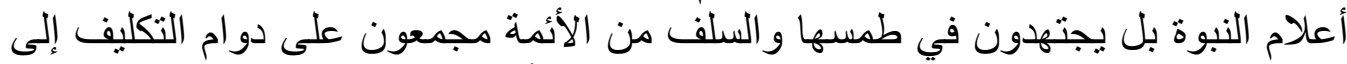

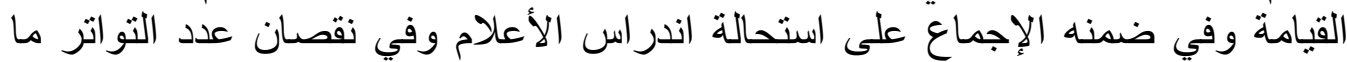

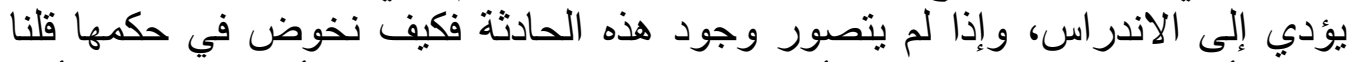

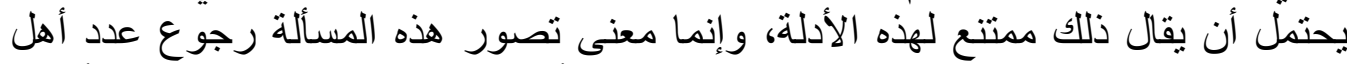

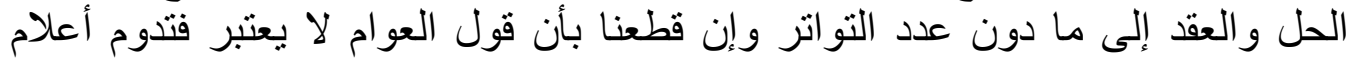

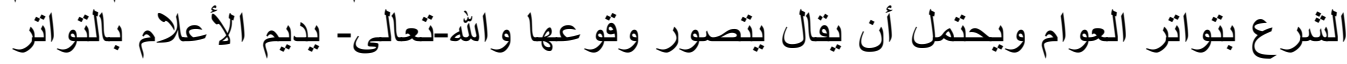

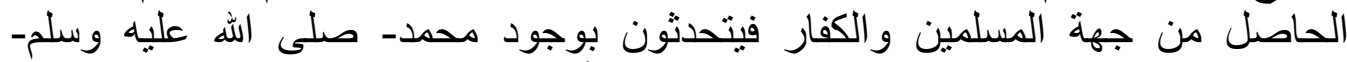

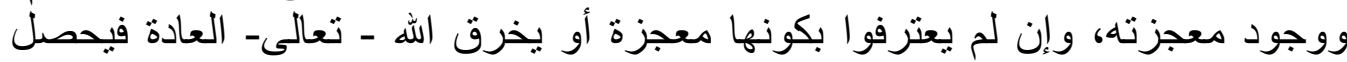

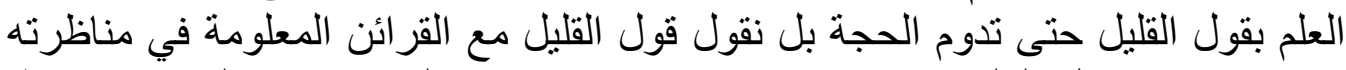

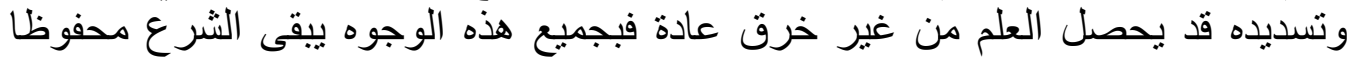

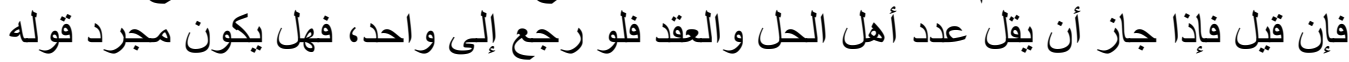

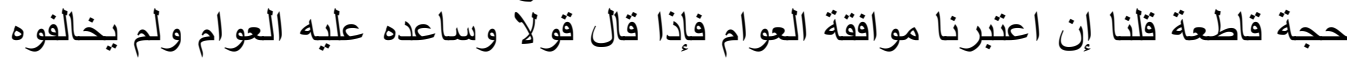

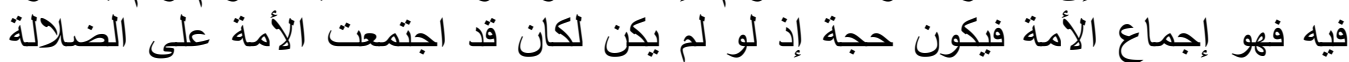

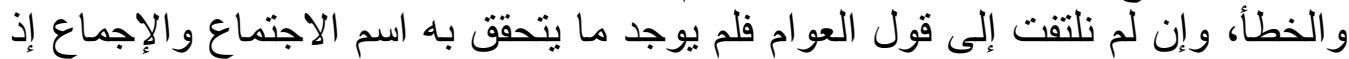

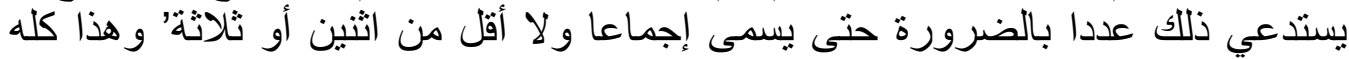

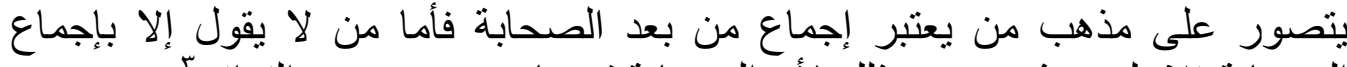

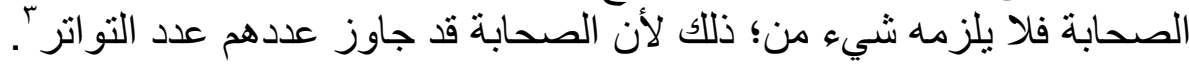

ـ المستصفى في علم الأصول المؤلف : محمد بن محمد الغزالي أبو حامد ، الناشر : دار الكتب العلمية ـ

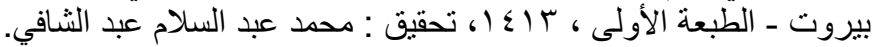

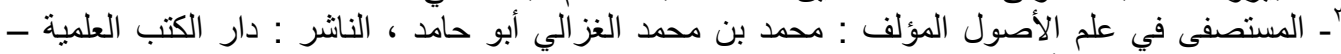

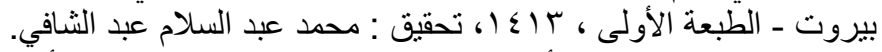

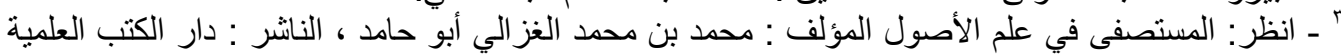

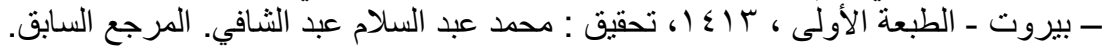




\section{الإبمث الثاني \\ أركان الإجماع وأنواعه}

المطلب الأول

أركان الإجماع الإع

وفيه مطلبان:

وفيه فرعان.

الفرع الأول: أركان الإجماع عند أبو حامد الغزالي:

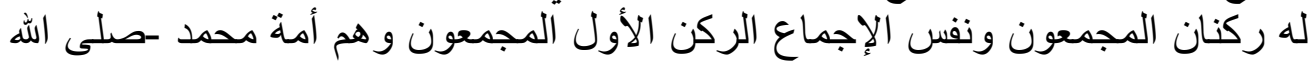

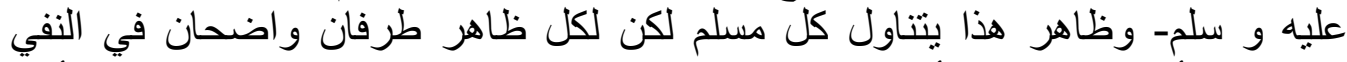

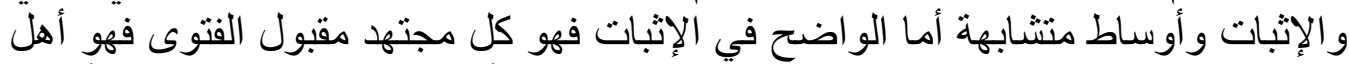

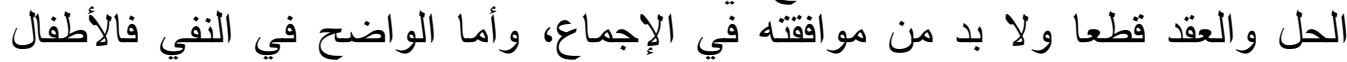

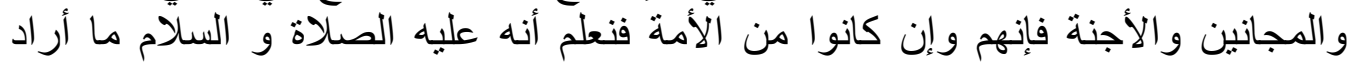

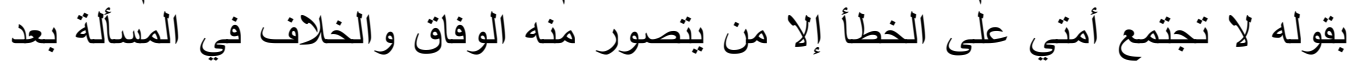

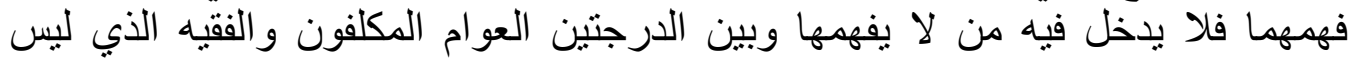

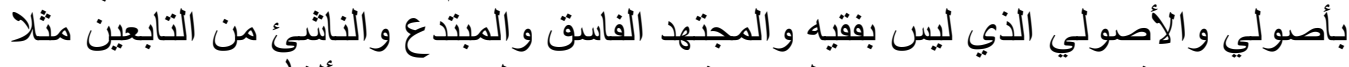

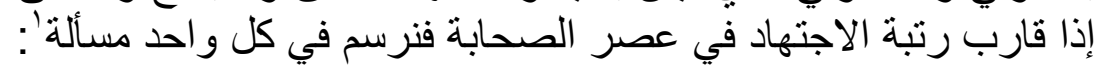

\section{المسألة الأولى: إجماع أهل الحل والعقد.}

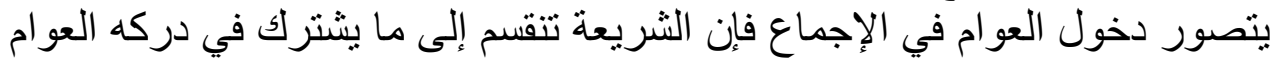

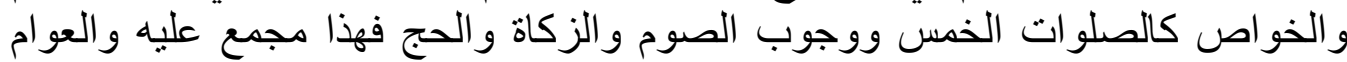

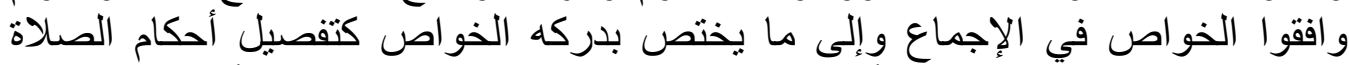

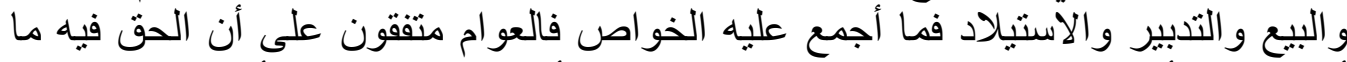

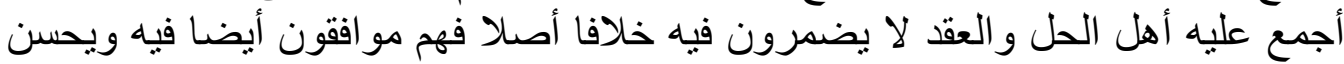

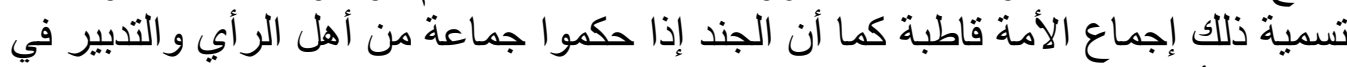

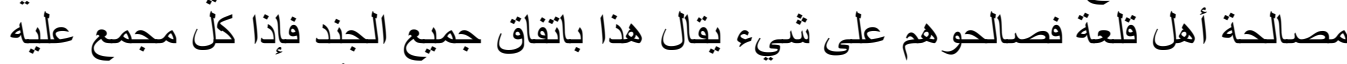

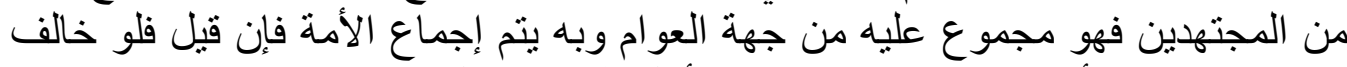

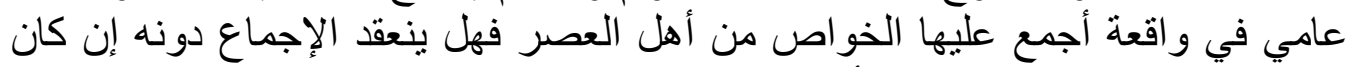

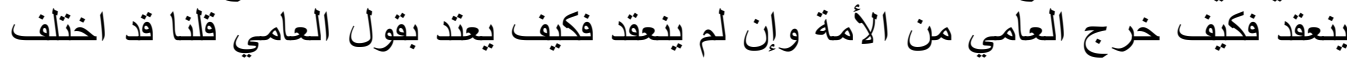

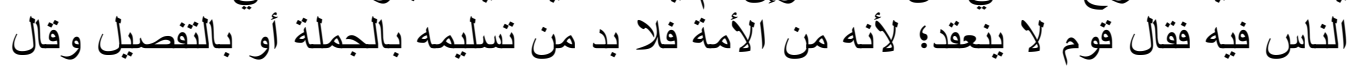

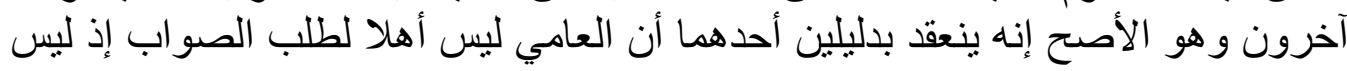

'ـ المستصفى في علم الأصول المؤلف : محمد بن محمد الغز الي أبو حامد ، الناشر : دار الكتب العلمية ـ بيروت ـ الطبعة الأولى ، با إـ (، تحقيق : محمد عبد السلام عبد الثافي. 
لله آلة هذا الثأن فهو كالصبي و المجنون في نقصان الآلة، ولا يفهم من عصمة الأمة من

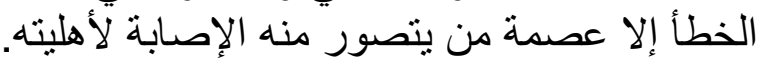

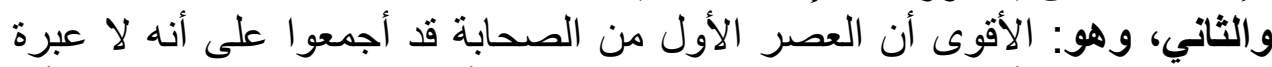

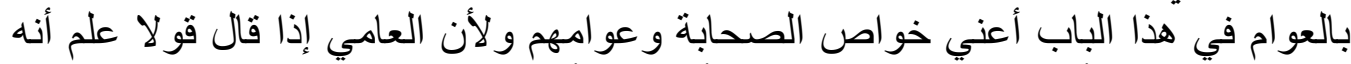

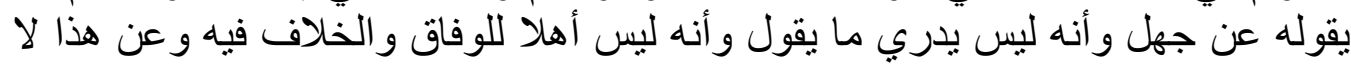

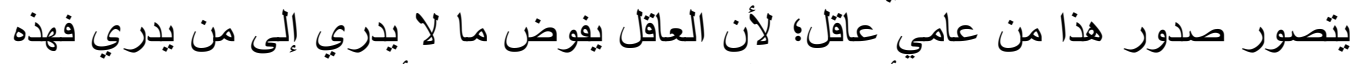

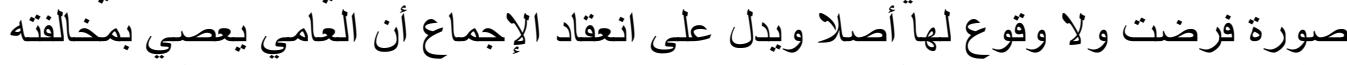

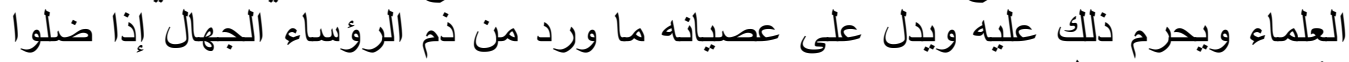

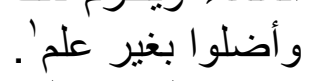

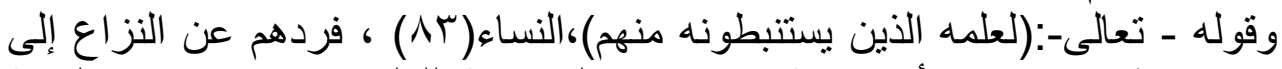

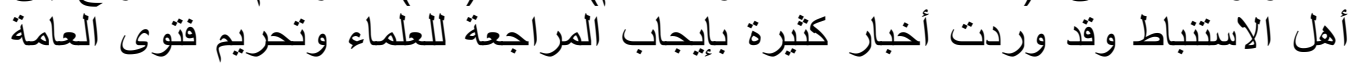

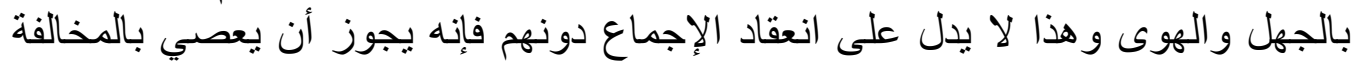

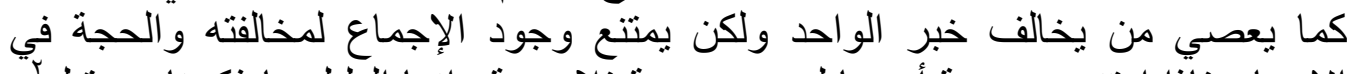

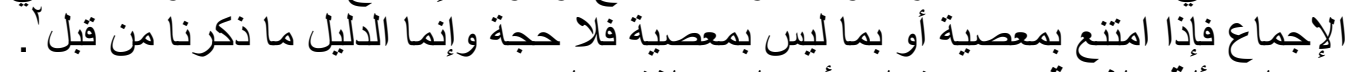

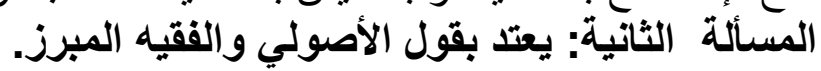

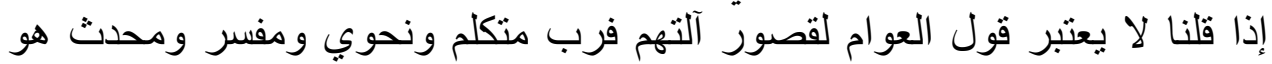

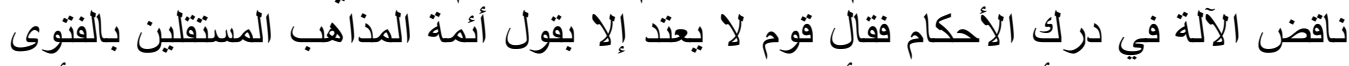

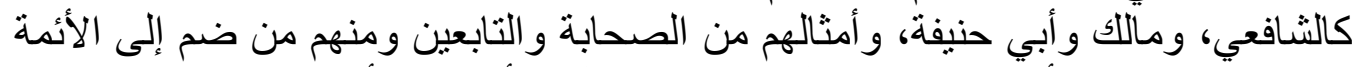

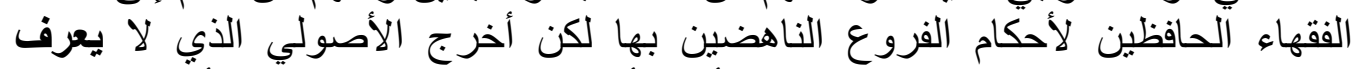

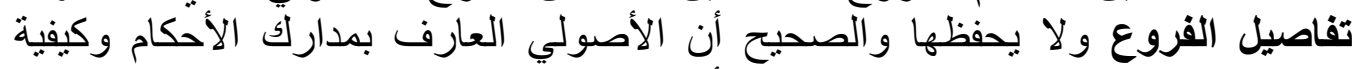

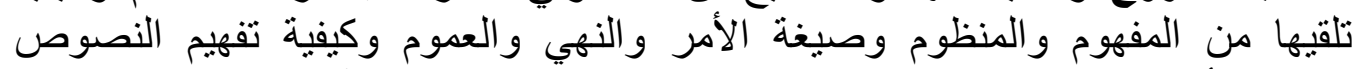

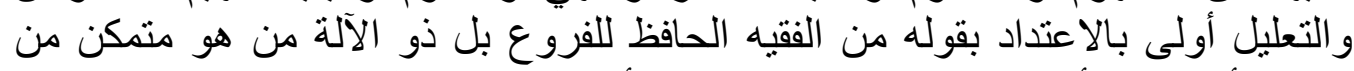

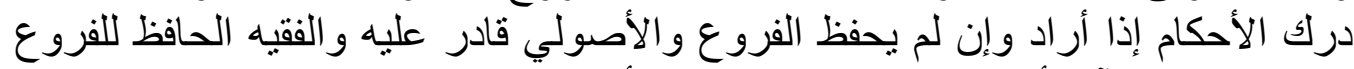

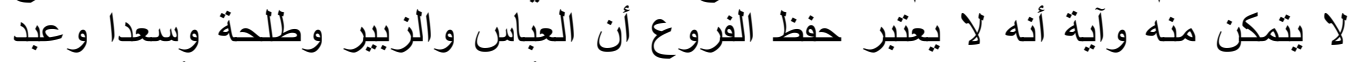

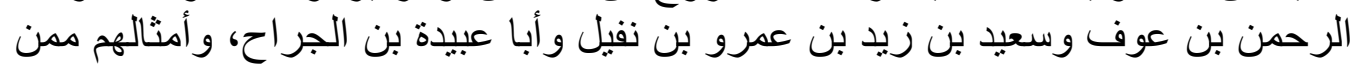

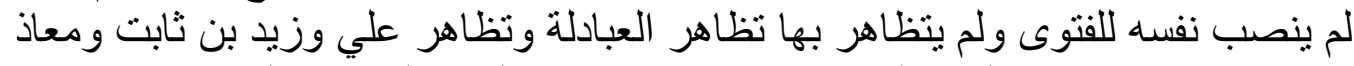

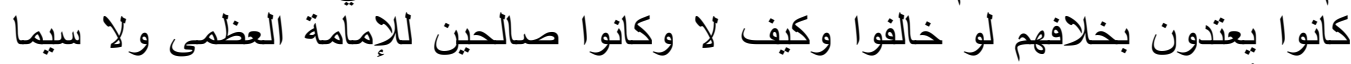

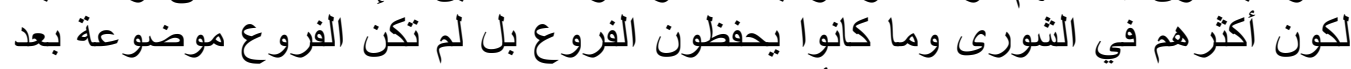

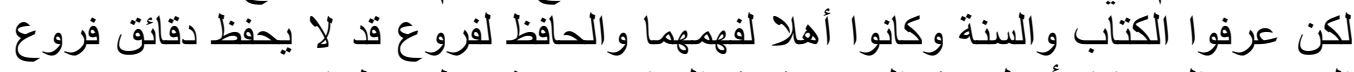

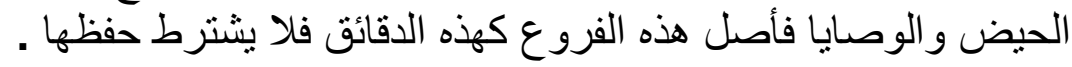

'ـ المستصفى في علم الأصول المؤلف : محمد بن محمد الغز الي أبو حامد ، الناشر : دار الكتب العلمية

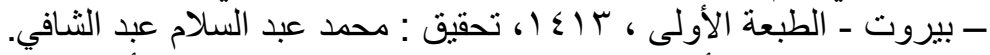

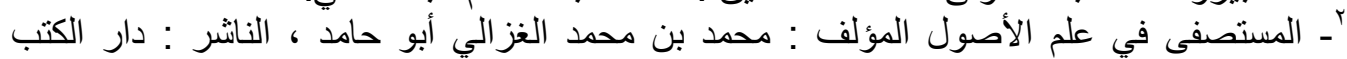
العلمية- بيروت ـ الطبعة الأولى ، باء إع ا، تحقيق : محمد عبد السلام عبد الثنافي. 


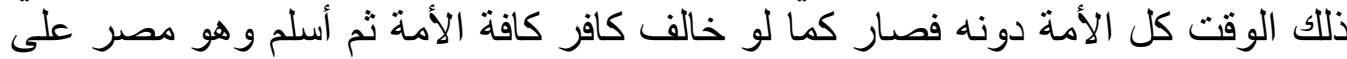

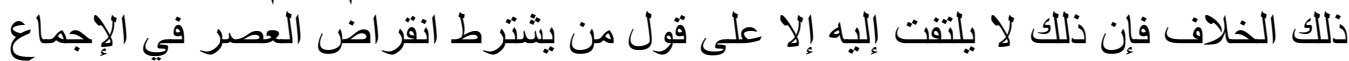

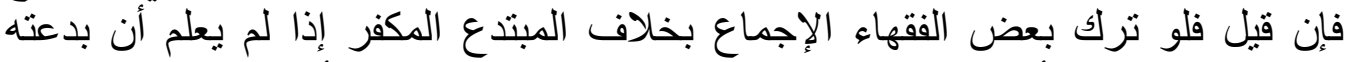

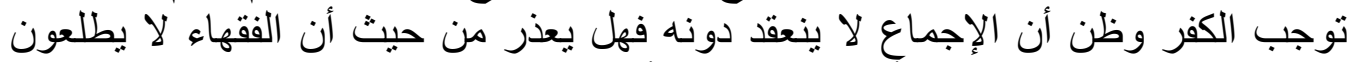

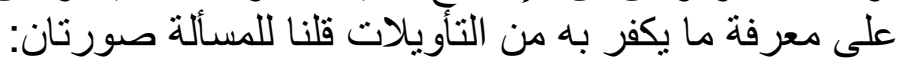

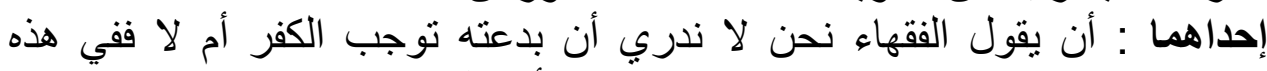

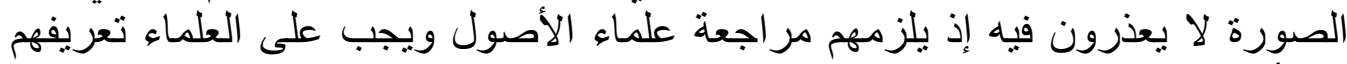

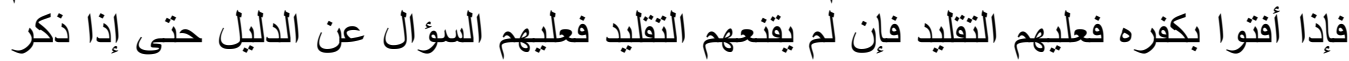

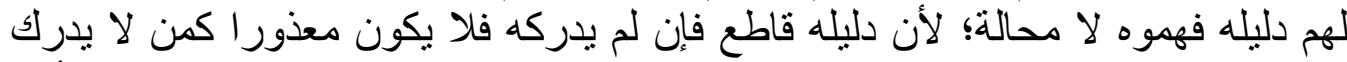

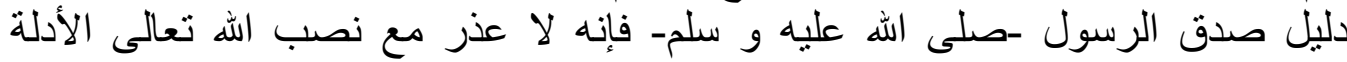

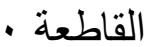
الصورة الثانية : أن لا يكون قد بلغته بدعته وعقيدته فترك الإجماع لمخالفته فهو

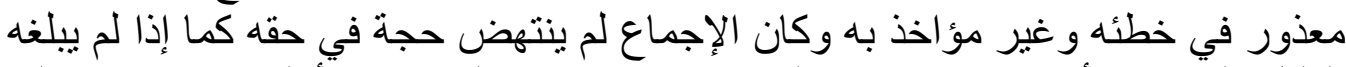

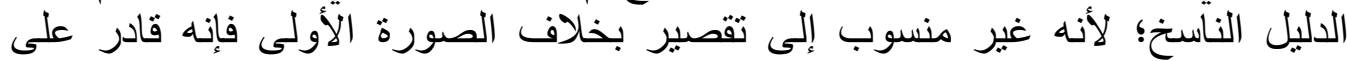

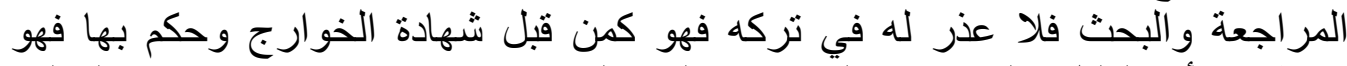

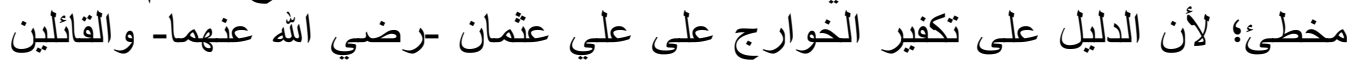

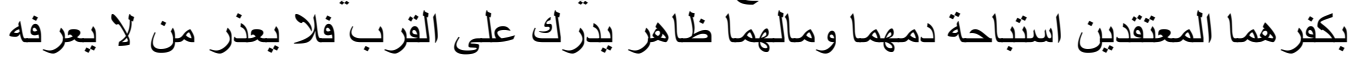

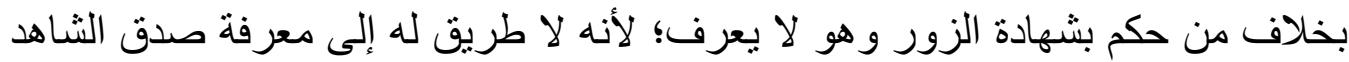

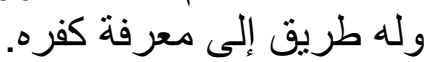
الثاني: ما يمنعه اعتقاده من الاعنر افت باف بالصانع وصفاته وتصديق رسله ويلزمه

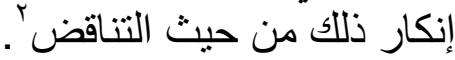
الثالث: ما ورد التوقيف بأنه لا يصدر إلا من كافر كعبادة النيران و السجود للصناف الصنم

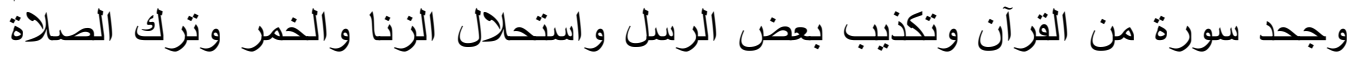

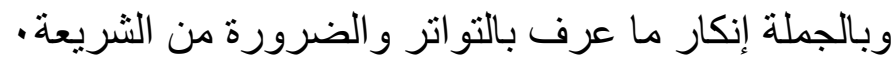

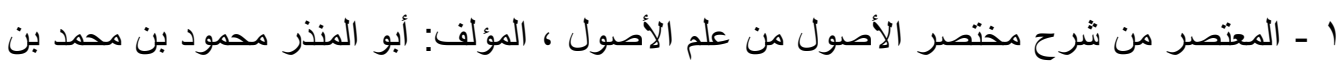

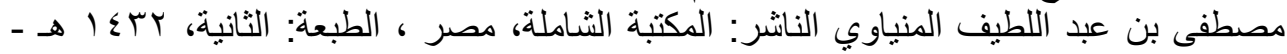
. $r .11$

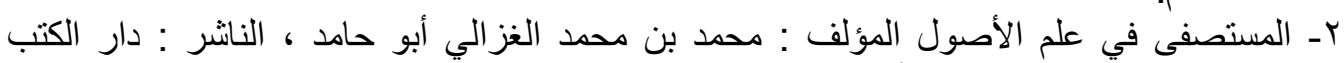

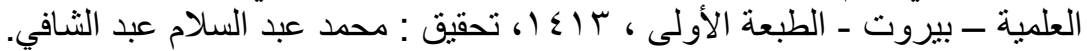




\section{المسألة الرابعة: هل ينعقد إجماع غير الصحابة.}

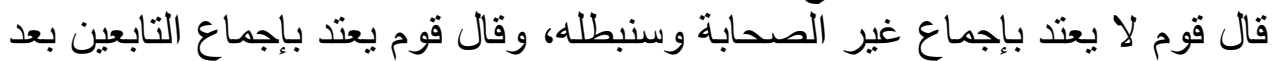

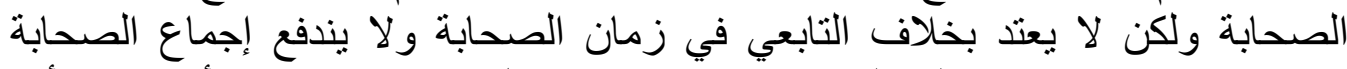

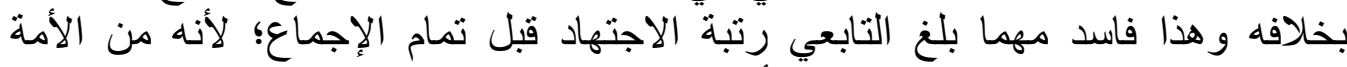

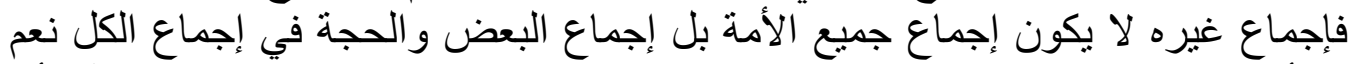

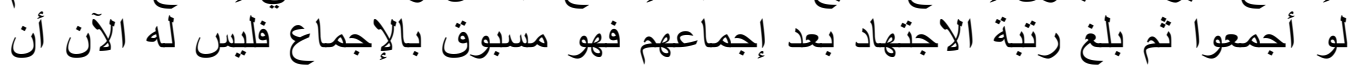

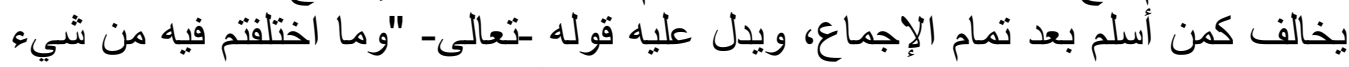

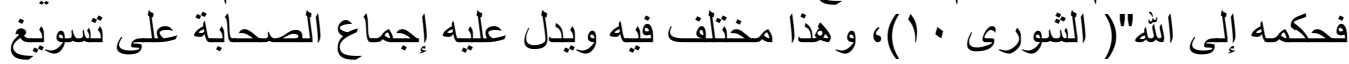

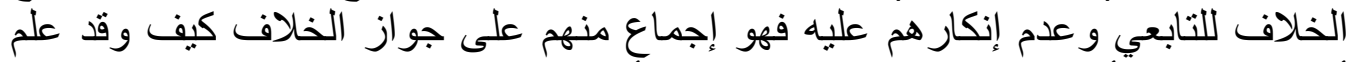

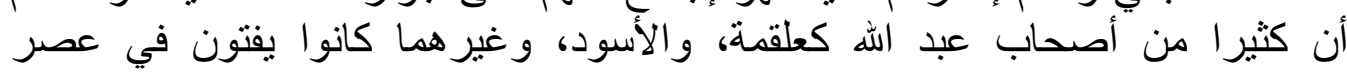

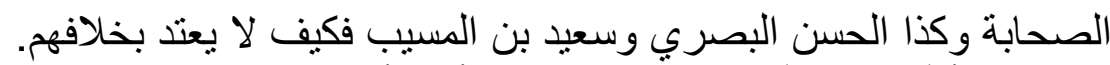

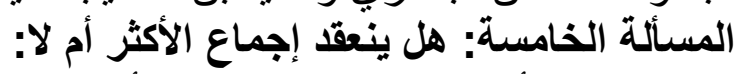

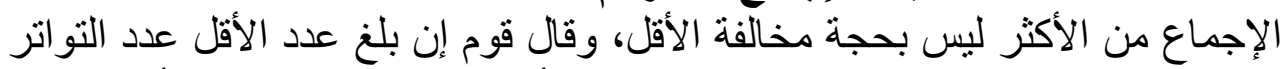

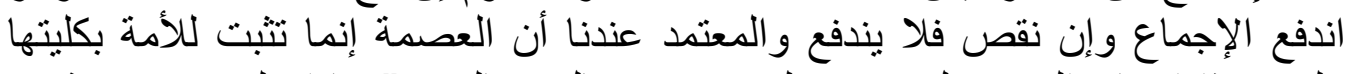

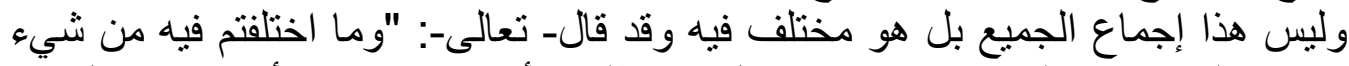

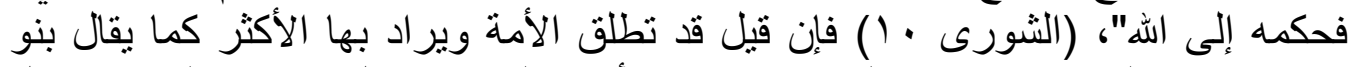

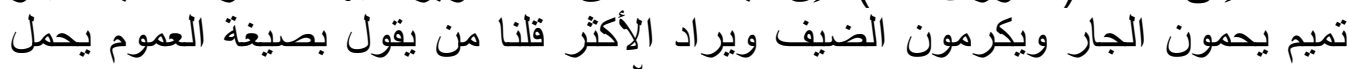

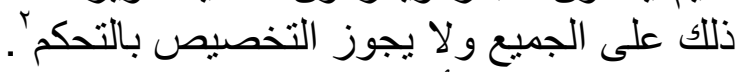

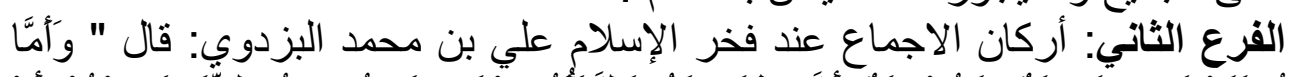

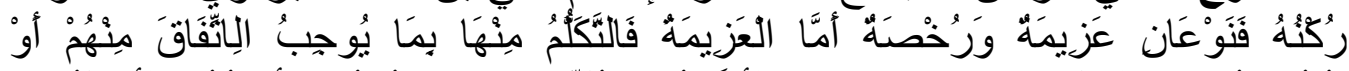

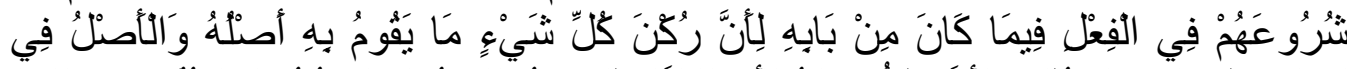

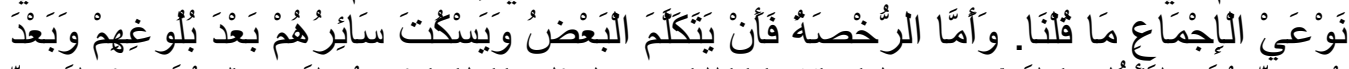

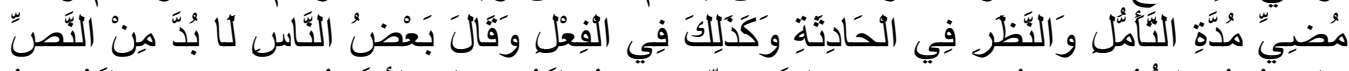

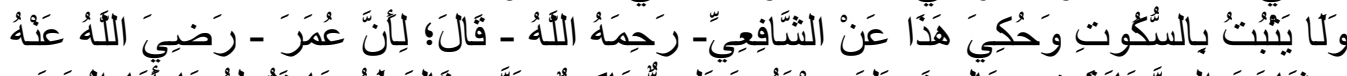

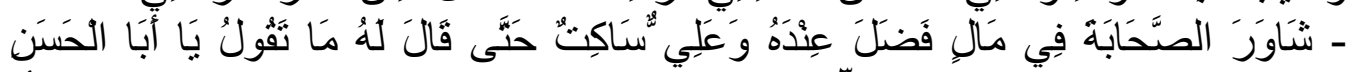

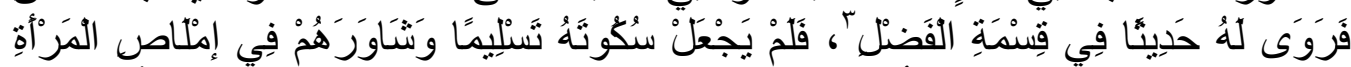

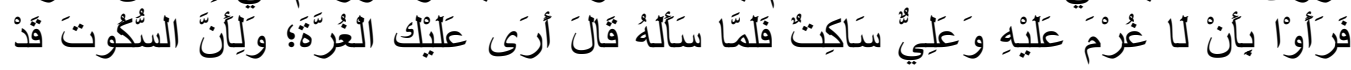

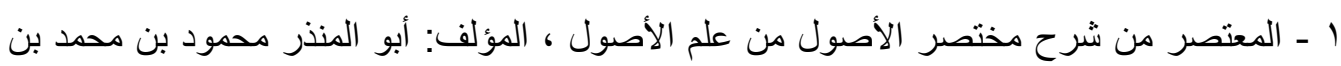

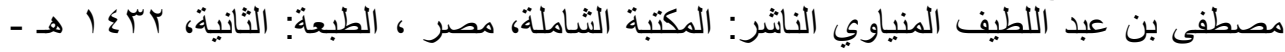

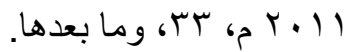

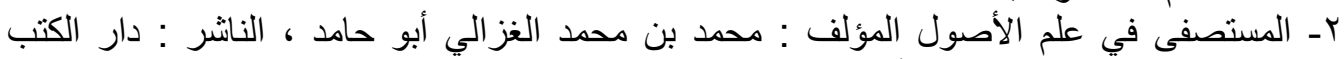

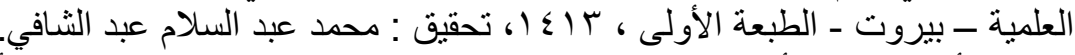

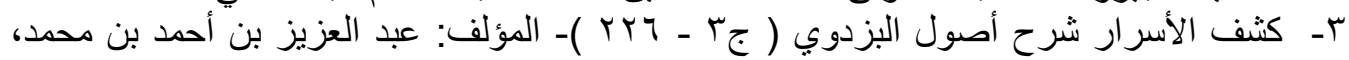

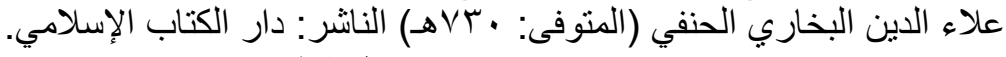




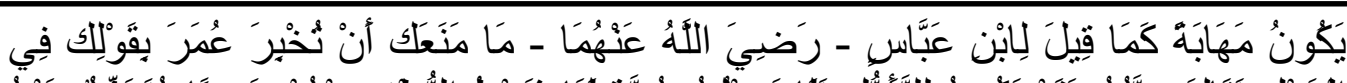

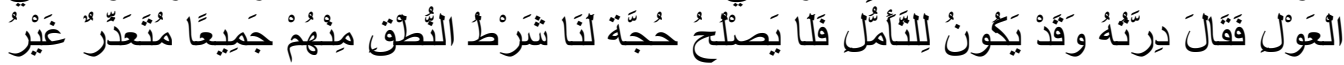

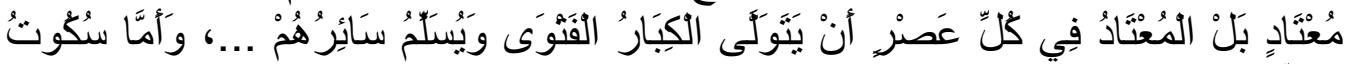

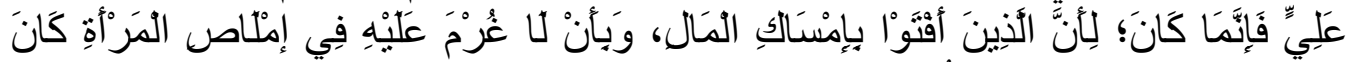

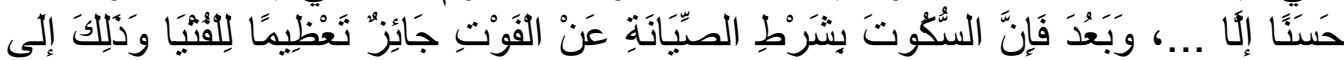

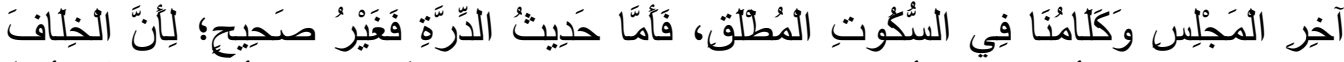

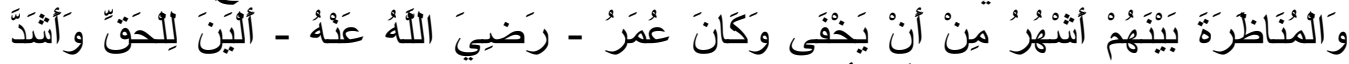

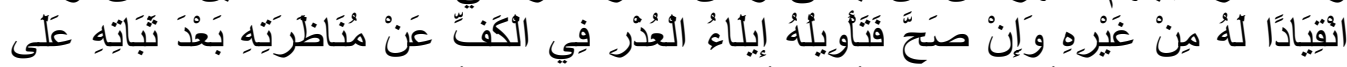

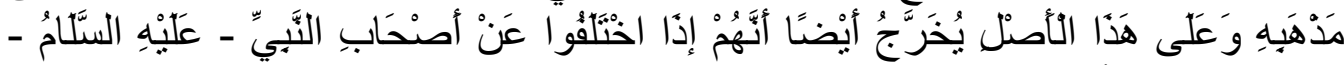

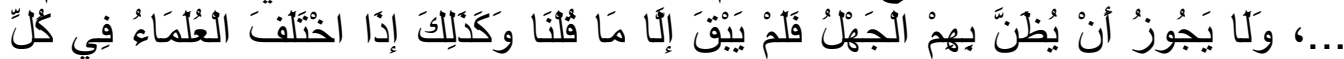

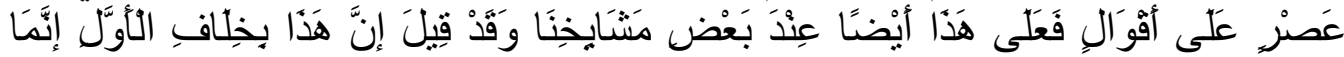

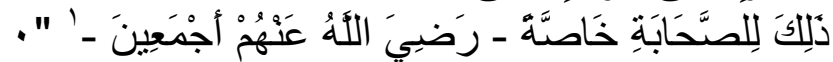

\section{المطالب الثنانـي}

\section{أنتواع الإجماع}

الإجماع نوعان: قطعي وظنيّ.

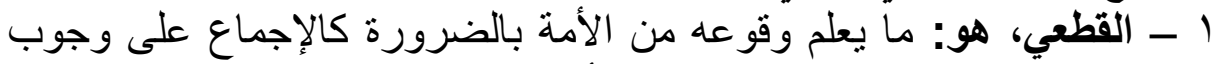

الصلوات الخمس وتحريم الزنى، وهذا النوع لا أحد ينكر ثبوته و لا كونه حجة، ويكفر

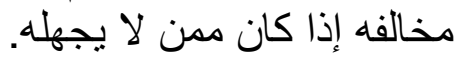

ץ - الظتي، هو: ما لا يعلم إلا بالتتبع والاستقراء. وقد اختلف العلماء في إمكان ثبوته، وأرجح الأقوال في ذلك رأي شيخ الإسلام ابن تيمية حيث قال في: العقيدة

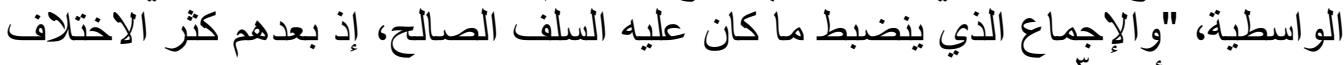

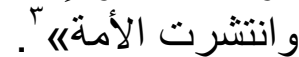

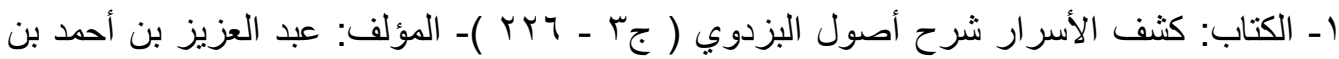

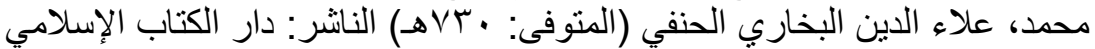

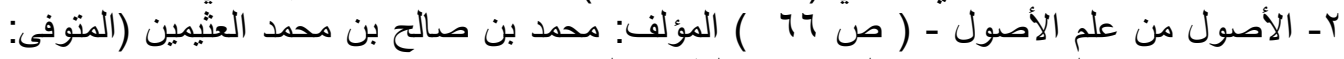

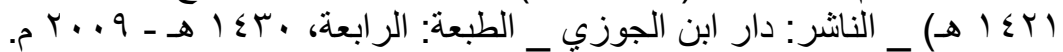

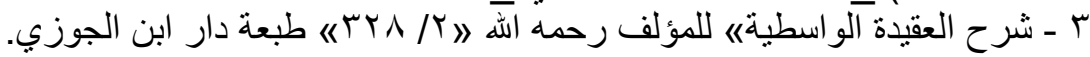




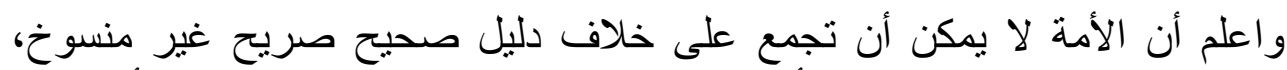

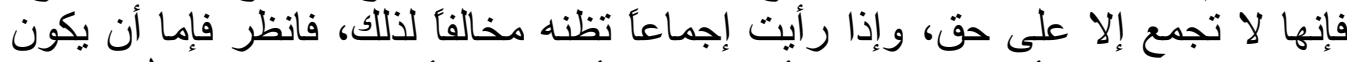

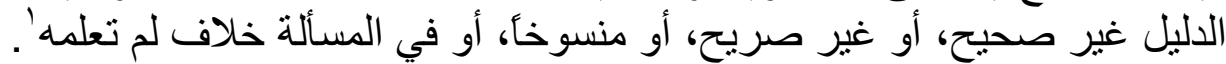

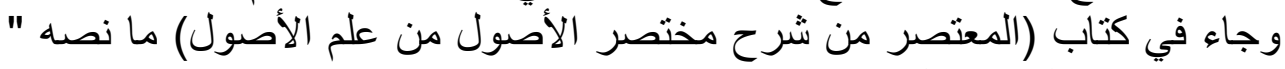

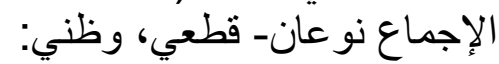

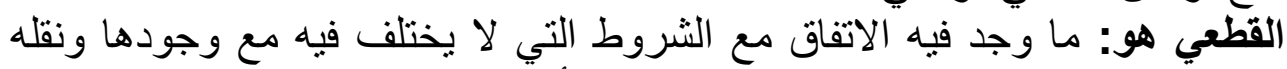

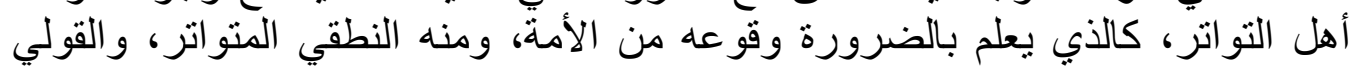

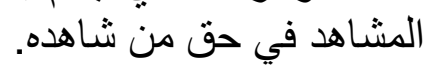
والإجماع الظني هو: ما تخلف فيه أحد القيدين (الاتفاق أو تحقق بعض الثروط) بأن أنان

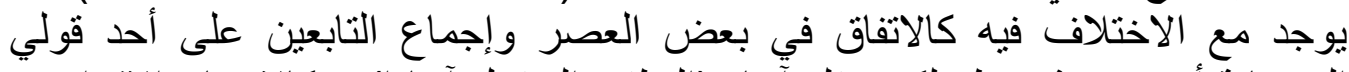

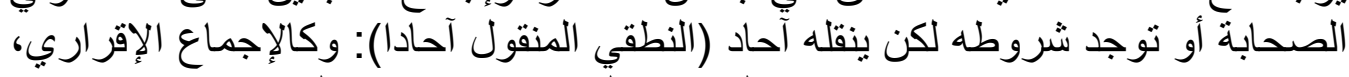

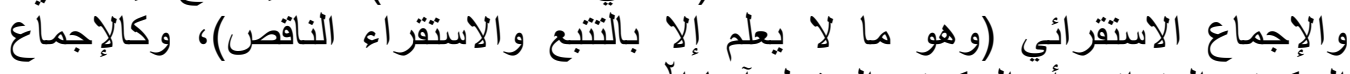

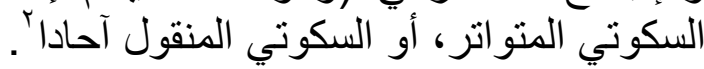

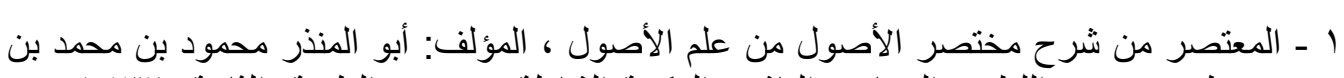

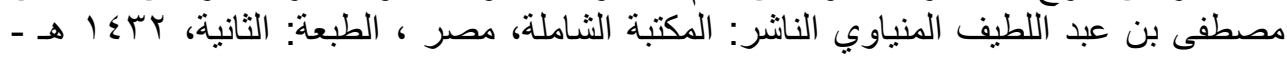

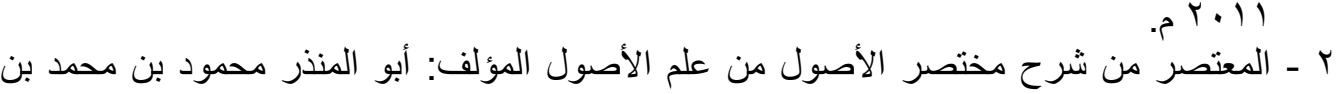

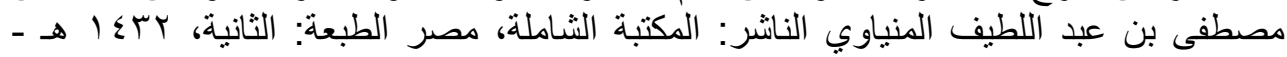




\section{المبمث الثالث}

\section{الأمكام المترتبة على الإجمماع}

$$
\begin{aligned}
& \text { إذا ثبت الإجماع فإن هنالك أحكامًا تترتب عليه: }
\end{aligned}
$$

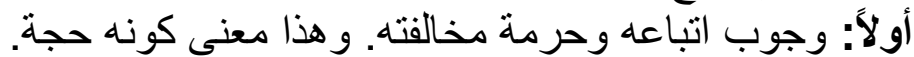

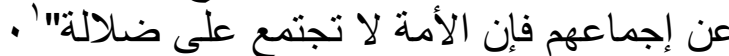

$$
\begin{aligned}
& \text { ويترتب على هذا الحكم ما يأتي: }
\end{aligned}
$$

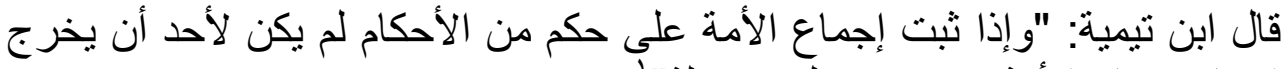

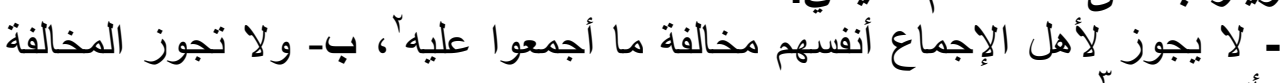

ثانيًا: أن هذا الإجماع حق وصو اب، و لا يكون خطأُويترتب على هذا الحكم ما يأتي :

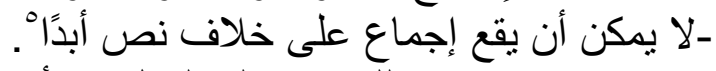

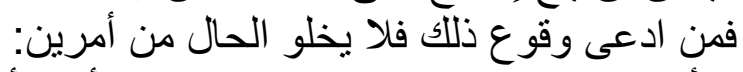

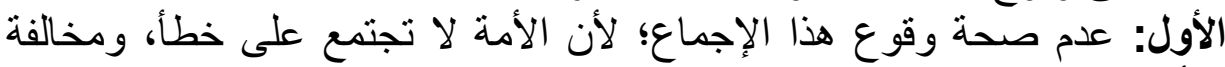

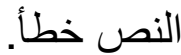

والثاني: أن هذا النص منسوخ، فأجمعت الأمة على خلافه استنادًا إلى النص

قال ابن القيم: "ومحال أن تجمع الأمة على خلاف نص إلا أن يكون له نص آخر

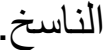

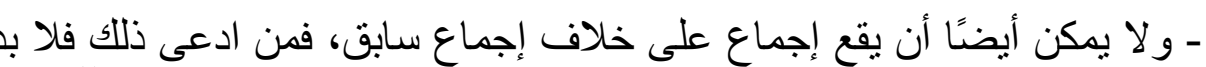

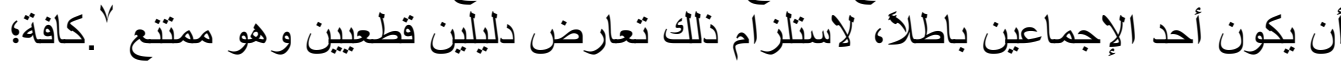

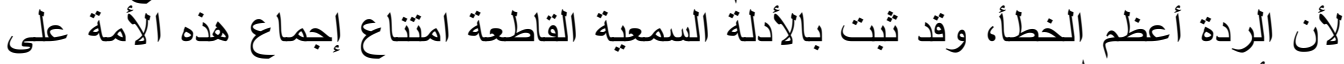

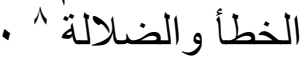

ا - مجموع الفتاوى • ب ص • إ لشيخ الاسلام ابن تيمية

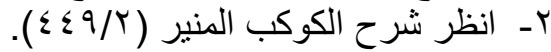

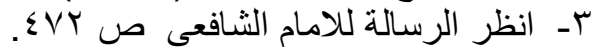

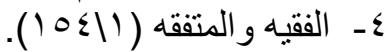

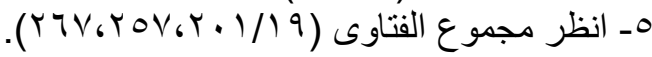

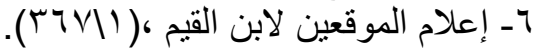

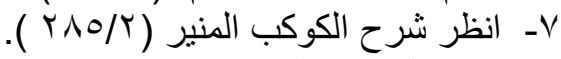




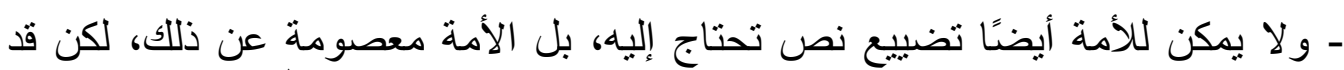

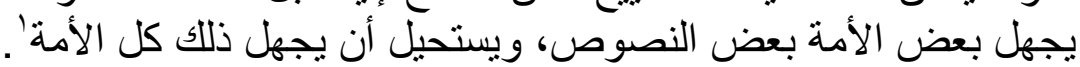

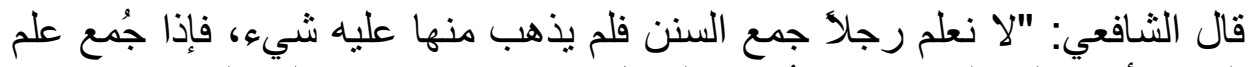

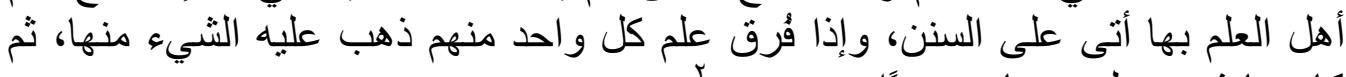

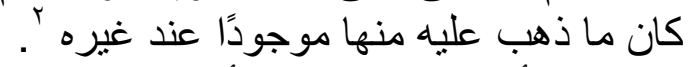

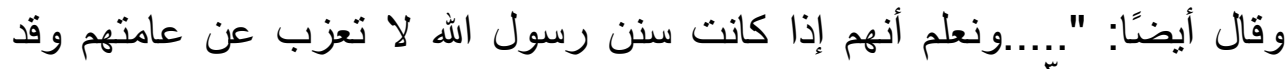

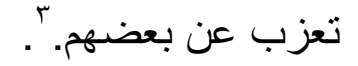

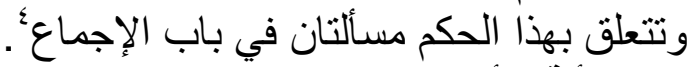

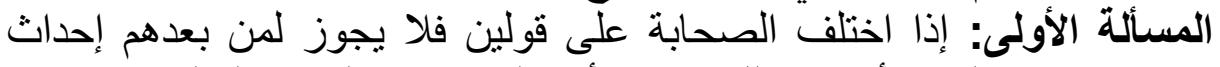

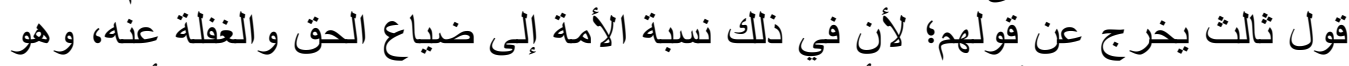

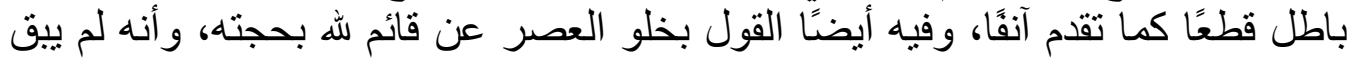

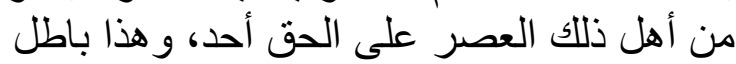

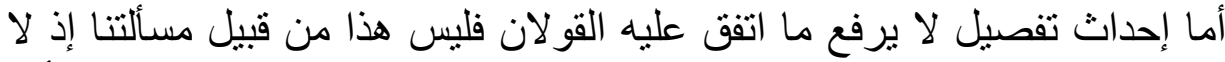

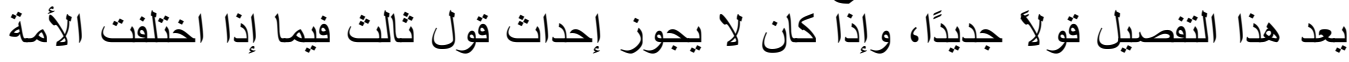

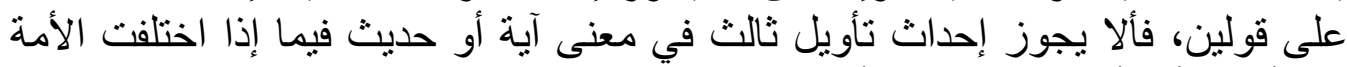

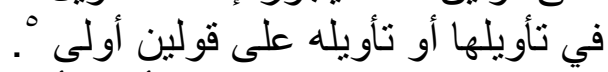

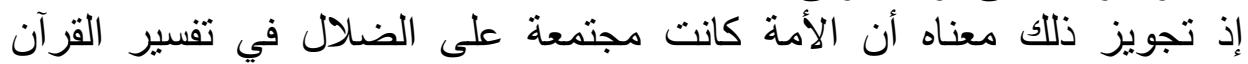

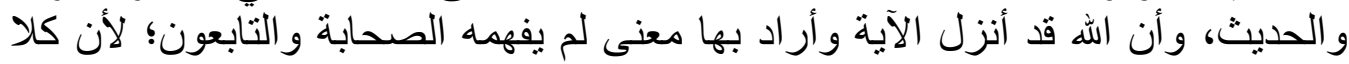

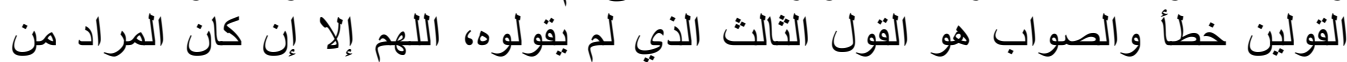

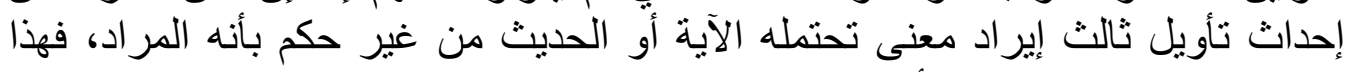

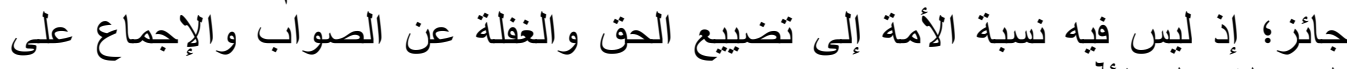

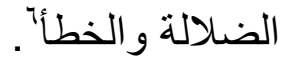

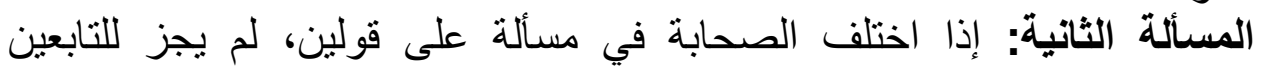

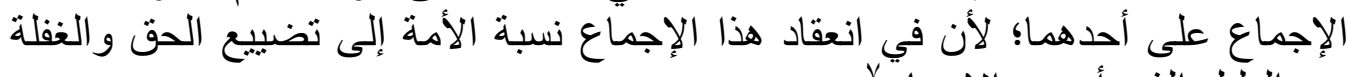

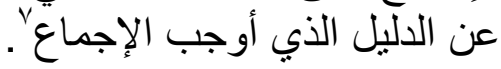

$$
\begin{aligned}
& \text { ا - مجموع الفتاوى ( } 9 \text { ( - ( • (Y). }
\end{aligned}
$$

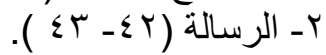

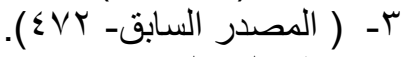

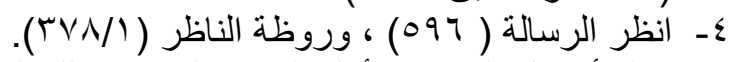

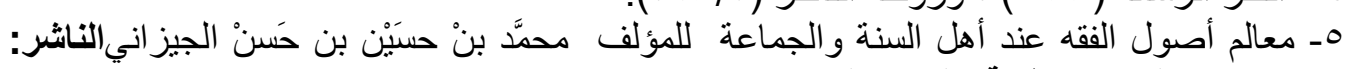

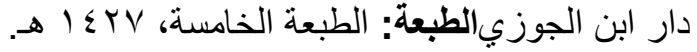

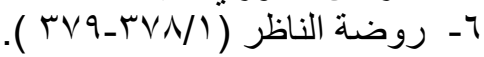

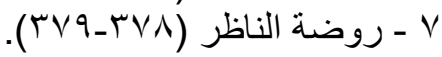


ولأن نزاع الصحابة واختلافهم لا يمكن أن يكون على خلاف الإجماع، فلا يصح

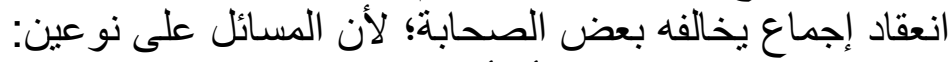

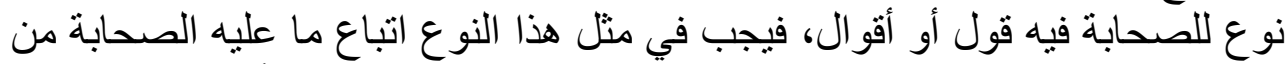

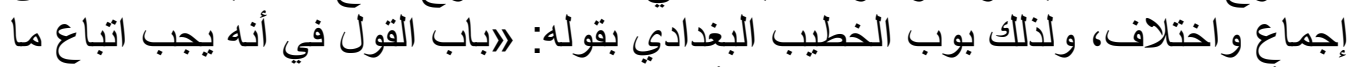

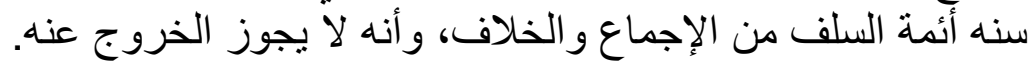

و النوع الآخر من المسائل هو المسائل الحادثة بعد الصحابة، والتي لم بنقل فيها

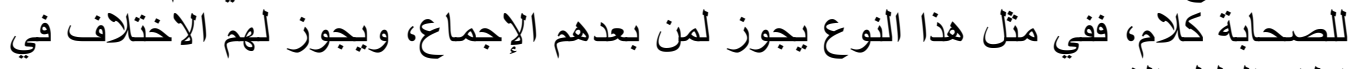
إطار الدليل الثرعي.

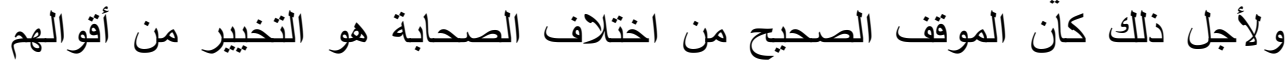
بالدليل، و اعتبار هذه المسألة التي اختلف فيها الصحابة من مسائل الاجتهاد التي ترد إلى التى التي الدليل ' الدليل'

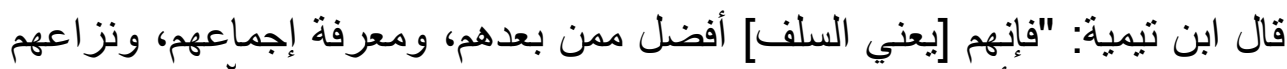

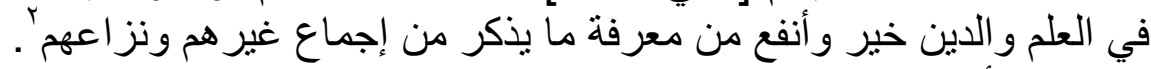

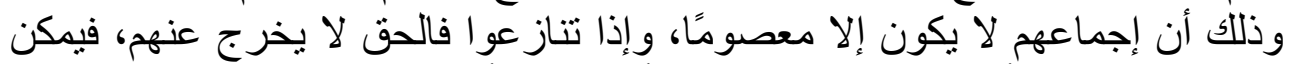

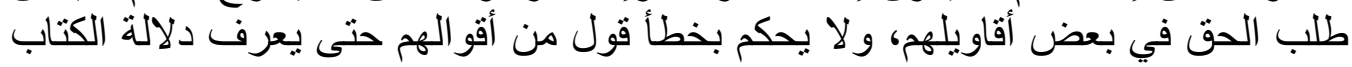

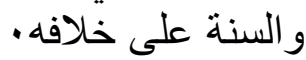
إذا تقرر ذللك فإنه لا بُسلم وقوع إنهاع إجماع على أحد قولي الصحابة، فمن ادعى وقوع ذللك فلا يخلو الحال من أمرين:

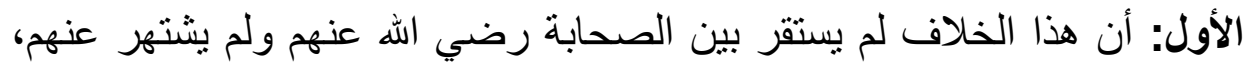

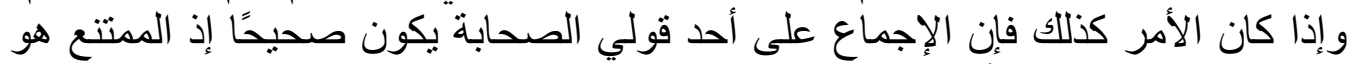

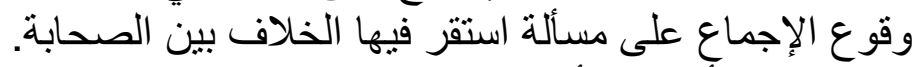

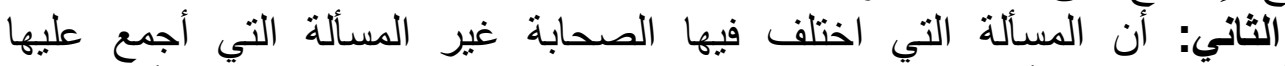

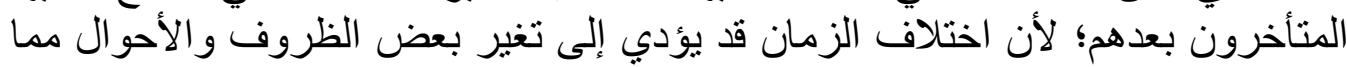

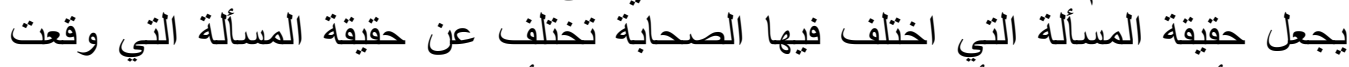

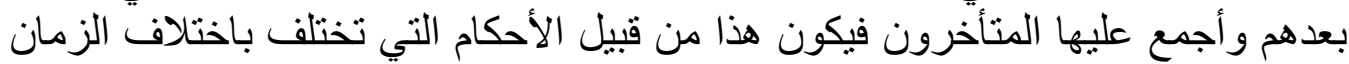

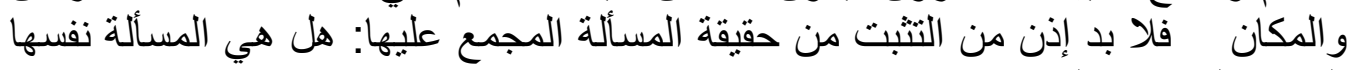
التي اختلف فيها الصحابة؟ 


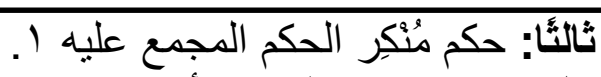
قال ابن تيمية: "و التحقيق أن الإجماع المعاع المعلوم يكفر مخالفه، كما يكفر مخالف النص

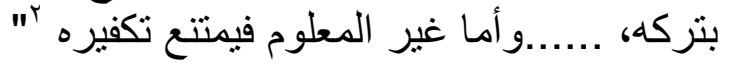

رابعًا: حرمة الاجتهاد؛ إذ يجب اتباع الإجماع، فإن الإجماع لا يكون إلا على نص،

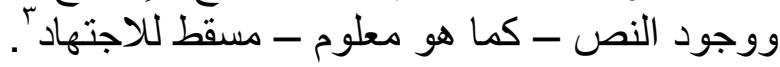

خامسًا: سقوط نقل دليل الإجماع، والاستغناء بنقل الإجماع عن نقل دليله، ويسقط أيضًا البحث عن الدليل اكتفاءً بالإجماعُ نلئ.

سادسًا: أن في الإجماع تكثيرًا للأدلة، خاصة وأن الحكم المجمع عليه قد دل عليه

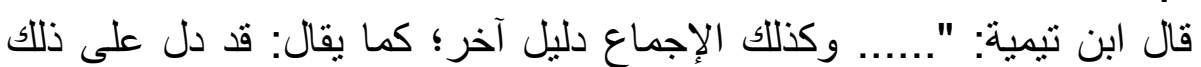
النص أيضًا.

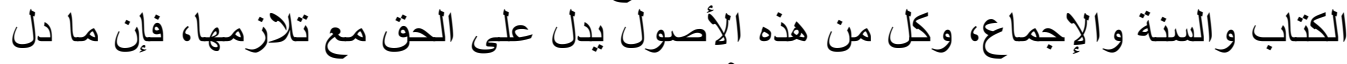

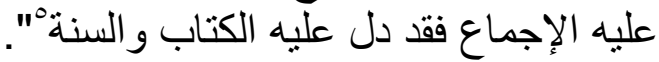

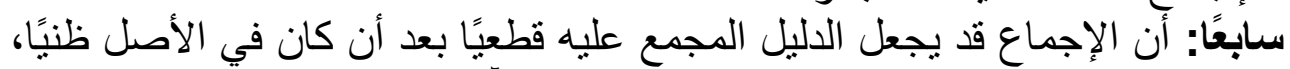

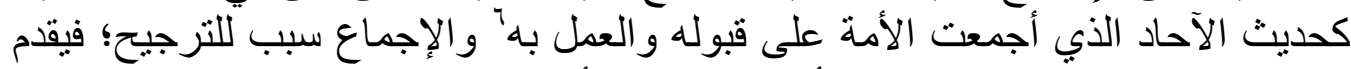
النص المجمع عليه على غيره، و لأجل ذللك قدم الأصوليون الإجماع على الإعلى الكتاب والسنة

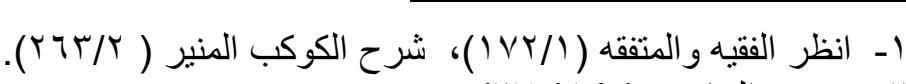

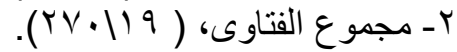

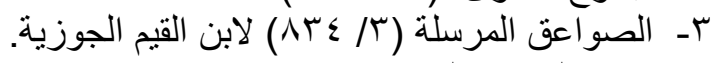

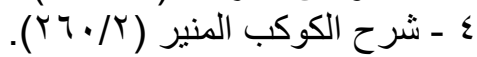

(1) م- مجموع الفتاوى ( 19019 (19).

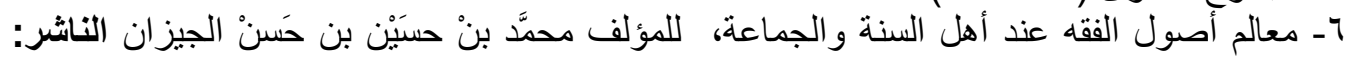

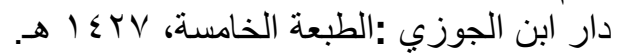




\section{الاببمث الرابع}

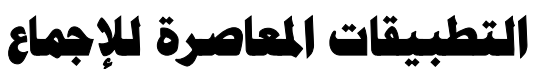

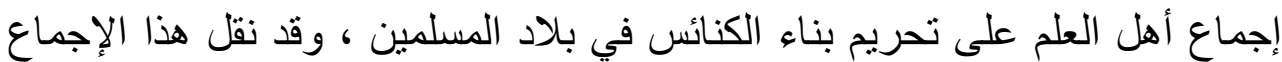

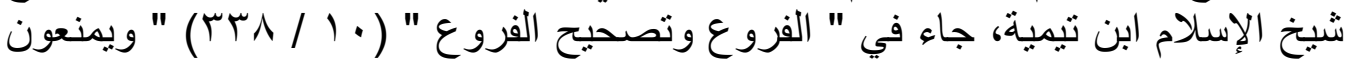

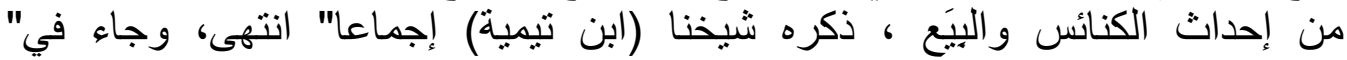

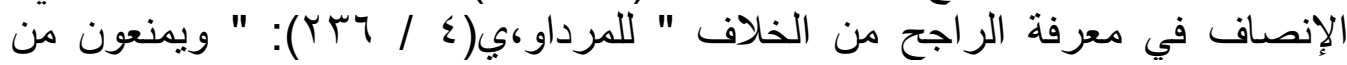

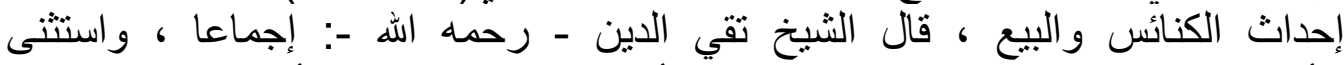

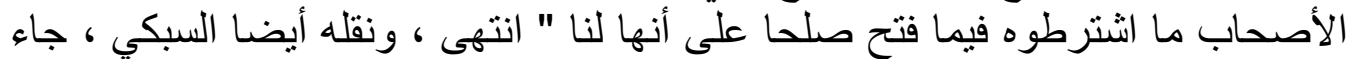

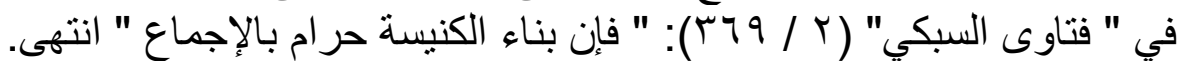

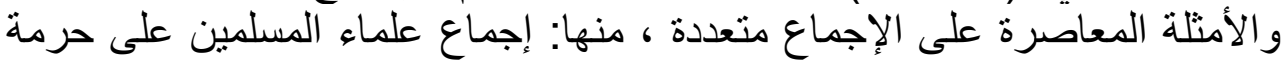

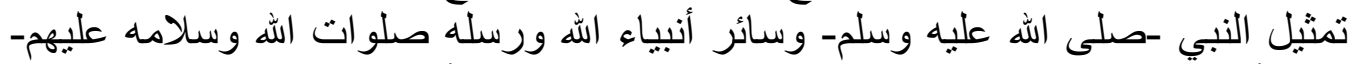

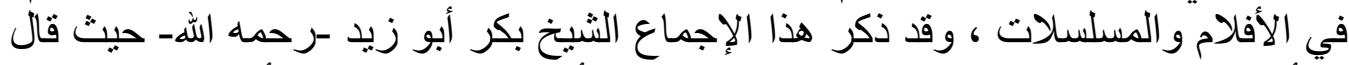

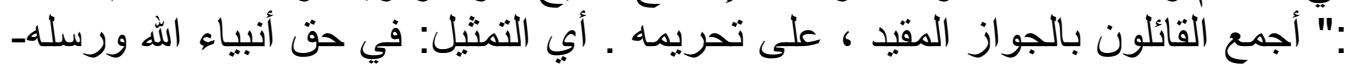

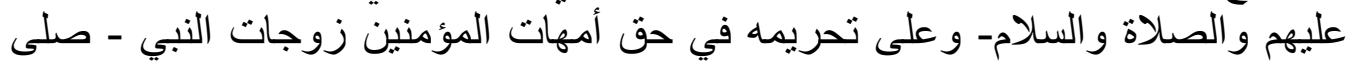

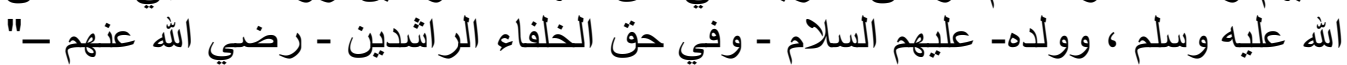

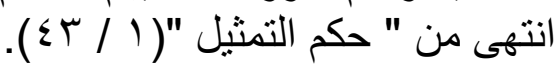




\section{الخاتمةة، وأهم النتائج}

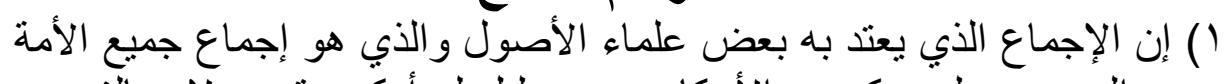

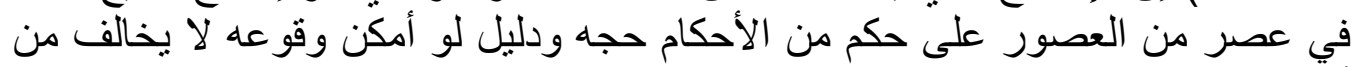

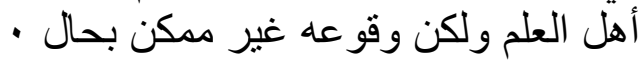

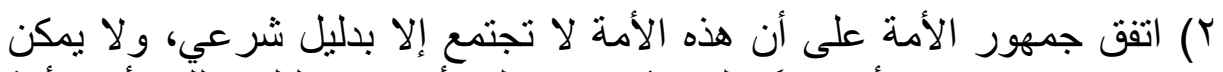

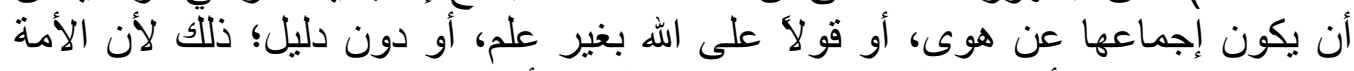
معصومة عن الخطأ، إذ القول على الله بدون دليل خطأ.

r) إن الإجماع قد يجعل الدليل الهمع عليه قطعيًا بعد أن كان في الأصل ظنيًا،

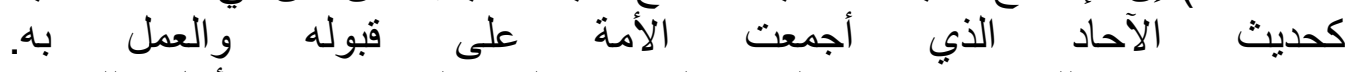
والإجماع سبب للترجيح؛ فيقدم النص المجمع عليه على غيره، ولأجل ذللك قدم لله الأصوليون الإجماع على الكتاب والسنة. 
مجلة كلية الثريعة والقانون بتفهنا الأشر اف ـ دقهلية

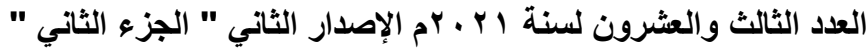

\section{ف ه

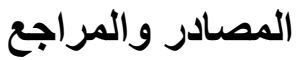

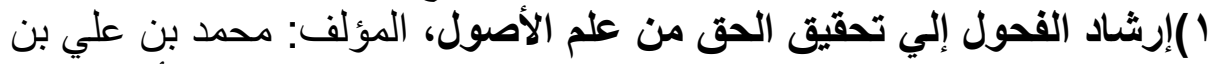

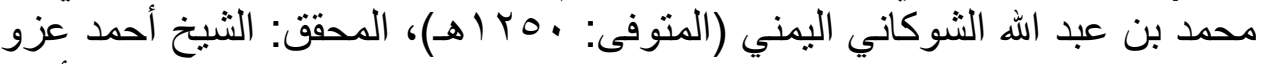

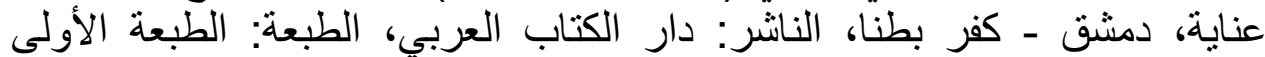
. ) $999-1$ - 19

ب)الأصول من عزم الأصول ،المؤلف: محمد بن صالح بن محمد العثيمين

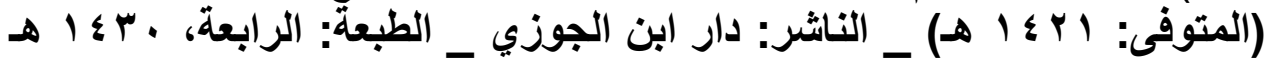
r. $\mathrm{r}$. ب)تعليق مختصر على كتاب لمعة الاعتقاد الهادي إلى سبيل الرشاد ، المؤلف:

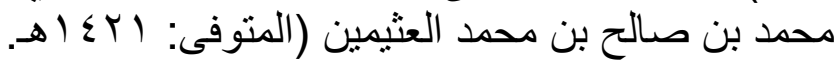

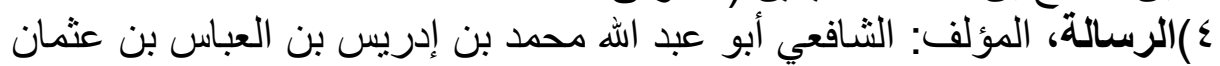

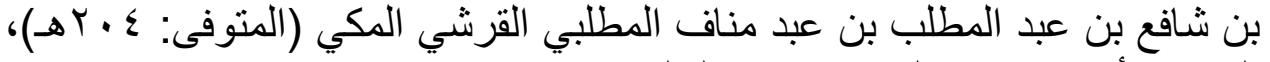

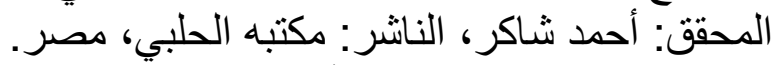

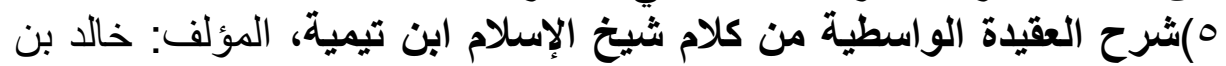

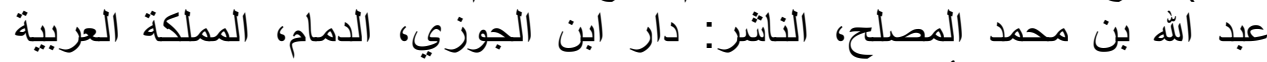

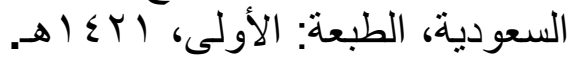

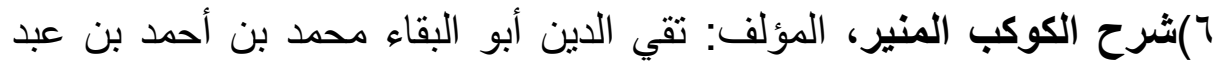

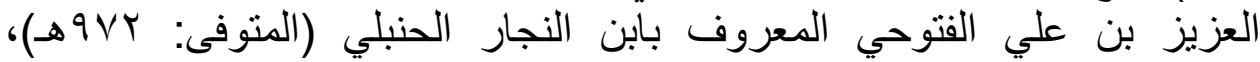
المحقق: محمد الزحيلي ونزيه حماد، الناشر: مكتبة العبيكان، الطبعة: الطبعة الثانية

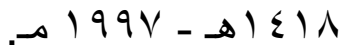
) ش شرح الكوكب المنير، المؤلف: تقي الدين أبو البقاء محمد بن أحمد بن عبد

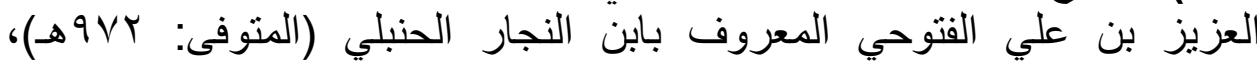
المحقق: محمد الزيلي حني ونزيه حماد، الناشر : مكتبة العبيكان.

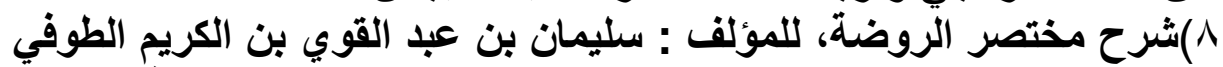

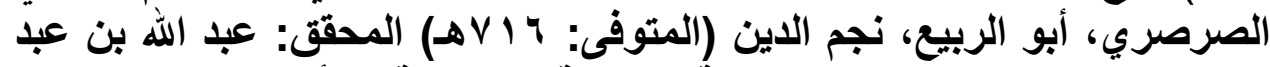

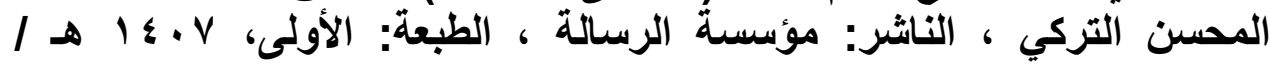
- $9 \wedge \mathrm{V}$

9)(العدة في أصول الفقه، المؤلف : القاضي أبو بعلى ، محمد بن الحسين بن

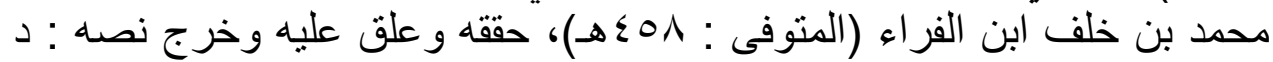

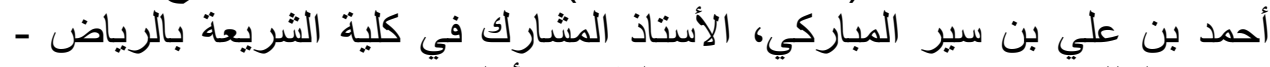

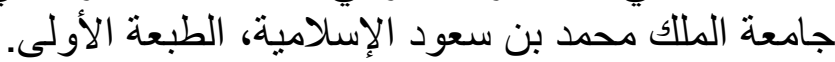

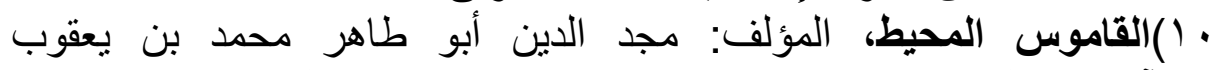
الفيروزآبادى (المتوفى: VIN Vهـ) تحقيق: مكتب تحقيق التراث في مؤسسة 


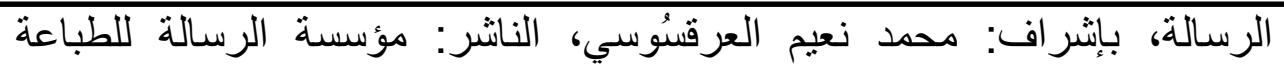

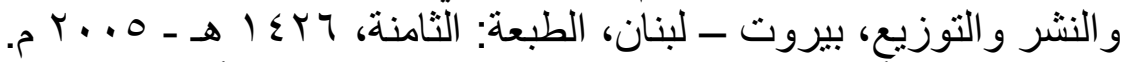

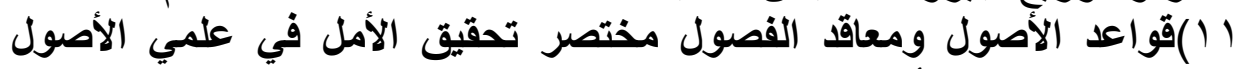

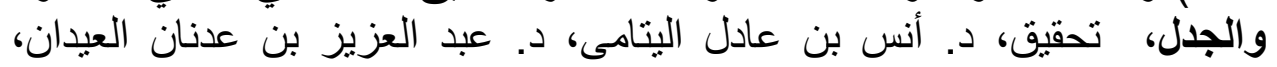

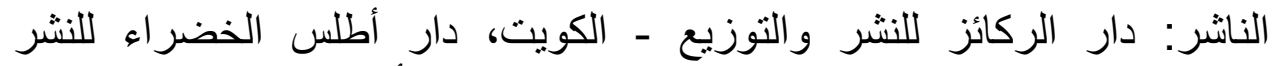

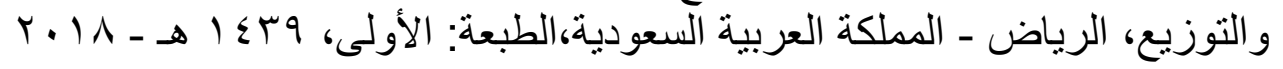

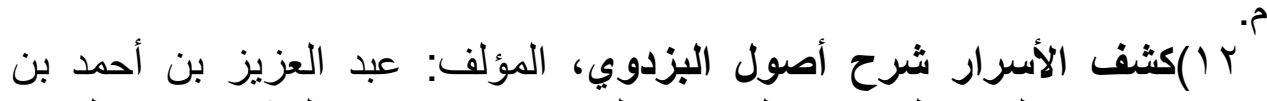

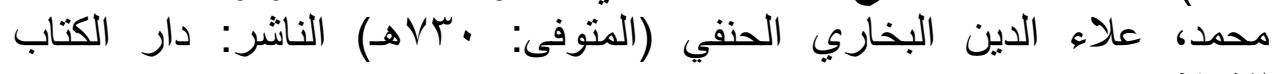

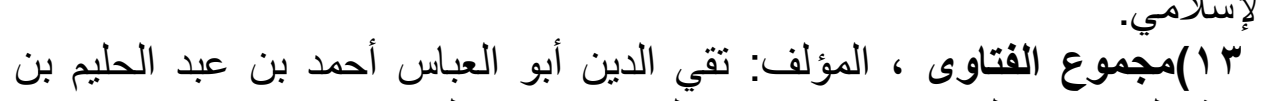

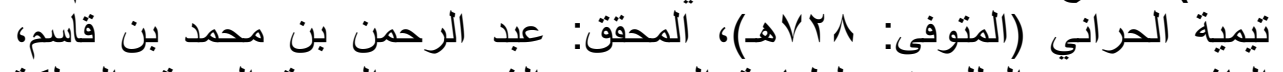

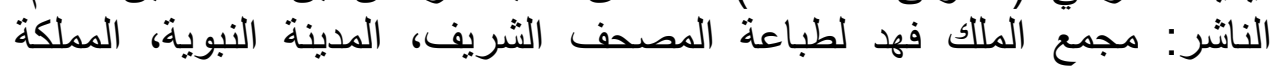

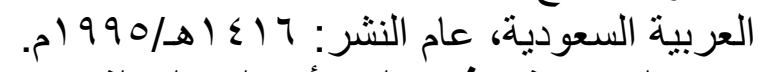

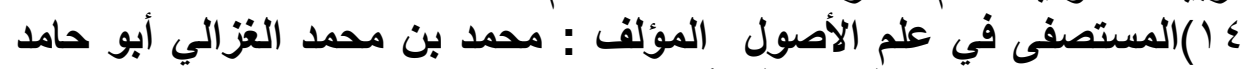

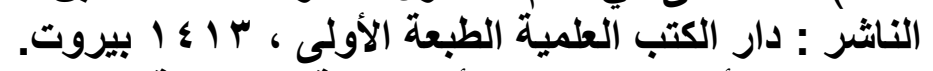

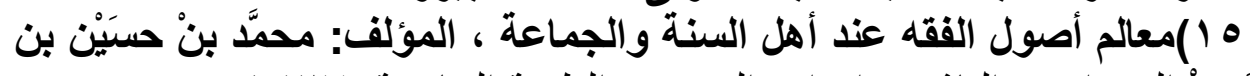

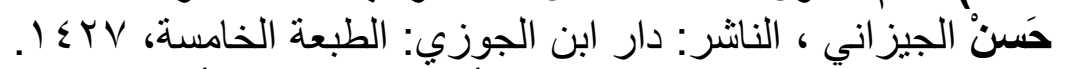

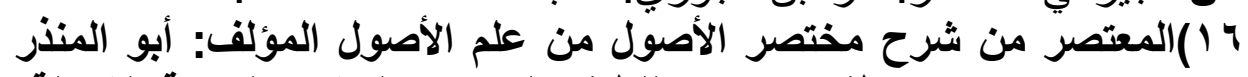

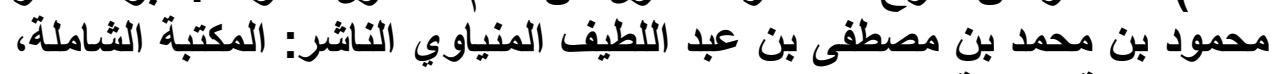

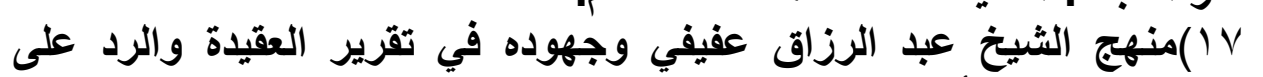

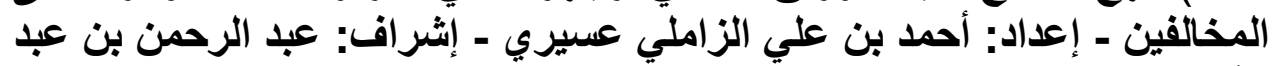

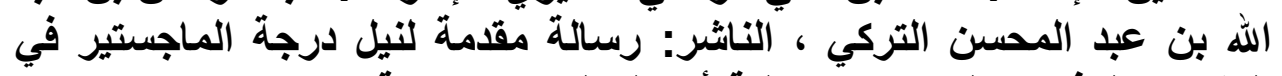

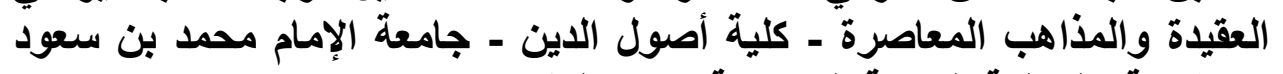

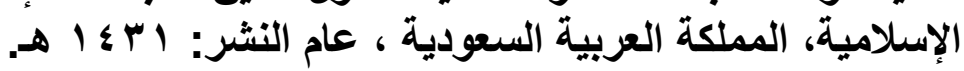

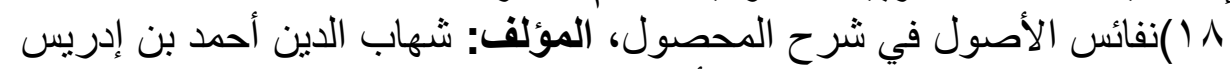

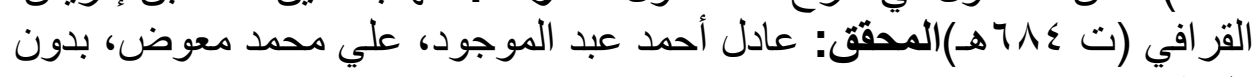
طبعة. 